\title{
Dinocyst assemblage constraints on oceanographic and atmospheric processes in the eastern equatorial Atlantic over the last $44 \mathrm{kyr}$
}

\author{
William Hardy ${ }^{1}$, Aurélie Penaud ${ }^{1}$, Fabienne Marret ${ }^{2}$, Germain Bayon $^{3}$, Tania Marsset ${ }^{3}$, and Laurence Droz ${ }^{1}$ \\ ${ }^{1}$ UMR 6538 Domaines Océaniques, IUEM-UBO, 29280 Plouzané, France \\ ${ }^{2}$ School of Environmental Sciences, University of Liverpool, Liverpool, L69 7ZT, UK \\ ${ }^{3}$ IFREMER, UR Géosciences Marines, BP 70-29280 Plouzané, France
}

Correspondence to: William Hardy (william.hardy@univ-brest.fr)

Received: 18 April 2016 - Published in Biogeosciences Discuss.: 21 April 2016

Revised: 2 August 2016 - Accepted: 8 August 2016 - Published: 29 August 2016

\begin{abstract}
A new 44 kyr long record of dinoflagellate (phytoplanktonic organisms) cysts (dinocysts) is presented from a marine sediment core collected on the Congolese margin with the aim of reconstructing past hydrological changes in the equatorial eastern Atlantic Ocean since Marine Isotopic Stage (MIS) 3. Our high-resolution dinocyst record indicates that significant temperature and moisture variations occurred across the glacial period, the last deglaciation and the Holocene. The use of specific dinocyst taxa, indicative of fluvial, upwelling and Benguela Current past environments for instance, provides insights into the main forcing mechanisms controlling palaeohydrological changes on orbital timescales. In particular, we are able, for the last $44 \mathrm{kyr}$, to correlate fluvial-sensitive taxa to monsoonal mechanisms related to precession minima-obliquity maxima combinations. While upwelling mechanisms appear as the main drivers for dinoflagellate productivity during MIS 2, dissolved nutrientenriched Congo River inputs to the ocean also played a significant role in promoting dinoflagellate productivity between approximately 15.5 and $5 \mathrm{kaBP}$. Finally, this highresolution dinocyst study permits us to precisely investigate the suborbital timing of the last glacial-interglacial termination, including an atypical warm and wet oceanic LGM signature, northern high-latitude abrupt climate change impacts in the equatorial eastern Atlantic, as well as a two-step decrease in moisture conditions during the Holocene at around 7-6 and 4-3.5 ka BP.
\end{abstract}

\section{Introduction}

Reconstructions of late Quaternary and Holocene palaeoceanographic changes at the western African margin and associated Benguela upwelling system have identified orbital and suborbital controls on sea-surface and continental environmental conditions (Holzwarth et al., 2007). More specifically, several palynological studies carried out in the equatorial eastern Atlantic Ocean, combining analysis of pollen grains and cysts of dinoflagellates (dinocysts), have provided a wealth of information on land-sea interactions in the intertropical region, through investigation of sea-surface and terrestrial vegetation changes over the last climatic cycles (Shi et al., 1998; Marret and Zonneveld, 2003; Dupont and Behling, 2006; Marret et al., 2008, 2013; Kim et al., 2010; Bouimetarhan et al., 2012). However, these above-mentioned studies mainly focused on the comparison between periods of extreme climatic conditions, such as the Last Glacial Maximum (Mix et al., 2001) and the Holocene climatic optimum, showing that higher primary productivity conditions occurred during glacial periods in response to an increase in upwelling activity while enhanced freshwater discharges from the continent occurred during interglacials. In comparison, the last deglaciation period, which consisted of a shift from upwelled cold waters (associated with dry conditions on land - glacial) to monsoonal regimes (associated with warm waters offshore - interglacial), has been less studied and its timing in this area remains poorly defined, mainly due to a lack of high-resolution investigations.

In this study, we have investigated a marine sediment core (KZAI-01) recovered during the ZaiAngo 1 cruise (Savoye et 
al., 2000) at the west African continental slope, upstream of the Congo deep-sea fan. This core is characterized by a high average sedimentation rate (about $25 \mathrm{~cm} \mathrm{kyr}^{-1}$, maximum of $50 \mathrm{~cm} \mathrm{kyr}^{-1}$ ) that enables high-resolution palaeoenvironmental records for the last $44 \mathrm{kyr}$ (Bayon et al., 2012). We combined here new dinocyst data with a set of already published geochemical data for sediment provenance and weathering proxies (Bayon et al., 2012). The comparison between terrestrial and marine proxy data can then be used to discuss the links between environmental changes that have occurred in the Congo catchment area and past sea-surface oceanography through dinoflagellate productivity variations.

Several objectives have motivated this study:

- to document the potential of dinocysts for reconstructing sea-surface environments in the eastern Atlantic Ocean and to discuss the links between continental and hydrological changes over the last $44 \mathrm{kyr}$

- to discuss orbital forcing impacts in our recorded dinocyst observations and the potential influence of the monsoonal activity on past sea-surface conditions

- to precisely characterize, in the equatorial Atlantic Ocean, the timing of the last deglaciation on a millennial timescale resolution.

\section{Environmental context on the Congolese margin}

The Congo River drains the second-largest catchment area of the world, with a total surface of $3600000 \mathrm{~km}^{2}$ and a mean flow of $41000 \mathrm{~m}^{3} \mathrm{~s}^{-1}$. This river feeds the Congo deep-sea fan (Babonneau et al., 2002; Droz et al., 2003; Savoye et al., 2009; Picot et al., 2016), one of the largest deep-sea fans in the world, via a submarine Pliocene canyon (Anka et al., 2009) still active at present (Heezen and Hollister, 1964; Khripounoff et al., 2003).

\subsection{Present-day atmospheric context}

Climatic patterns in the Congo Basin are controlled by the seasonal latitudinal migration of the tropical rain belt (TR; Fig. 1), which is associated offshore with high sea-surface temperatures (SSTs) and low salinities (Zarriess and Mackensen, 2010; Arbuszewski et al., 2013). This low-pressure belt is characterized by moist air ascension and large tropical rainstorms, generated by the association of the tropical and African easterly jets in the Northern Hemisphere (Nicholson, 2009). The TR and the Inter Tropical Convergence Zone (ITCZ) constitute the complex convective system of the African monsoon system, which shifts seasonally from a northward position during boreal summer to a southward position during boreal winter (Hsu and Wallace, 1976). While the central part of the Congo Basin is characterized by an equatorial regime, its northern and southern parts alternate between wet and dry seasons (Prance, 1984; Leroux,
2001). This results in a latitudinal distribution of the vegetation from rainforests to savannahs across the whole basin (Prance, 1984). Easterly winds from the Indian Ocean also bring moisture to the Congo Basin, in particular during the austral summer, due to the presence of the Congo Air Boundary convergence zone (CAB; Tierney et al., 2011), also evidencing the influence of the eastern African monsoon system in central Africa.

\subsection{Present-day oceanographic context}

Surface water masses from the Congolese margin are largely influenced by the Angola Current (AC; Fig. 1), a clockwise subequatorial gyre located above the north-eastern part of the subtropical gyre (Lass and Mohrholz, 2008). The warm waters of the $\mathrm{AC}$ meet the cool waters of the coupled Benguela Current and coastal Benguela Current (BC and CBC; Fig. 1) at around $16^{\circ} \mathrm{S}$ at the Angola-Benguela Front (ABF; Lass and Mohrholz, 2008). Cool surface currents cause weak evaporation and aridity conditions on the adjacent continent (Gordon et al., 1995), as well as water mass stratification on the continental shelf, itself depleted in oxygen (Gordon et al., 1995).

The South Atlantic anticyclone, driving the Subtropical Gyre, generates SE trade winds on the SW African margin and consequently upwelling cells throughout the BC (Gordon et al., 1995; Lass and Mohrholz, 2008). These upwelled waters bring deep nutrient-rich waters that promote high primary productivity in surface waters. The Benguela upwelling system is limited northward around the ABF location (Jansen et al., 1996; Lass and Mohrholz, 2008).

Congo River freshwater discharges also exert an influence on the regional oceanographic setting, in particular because of the relative weakness of the Coriolis force near the equator that allows river plumes to extend far from the coast (da Cunha and Buitenhuis, 2013). This mechanism also contributes to enhanced fluvial upwelling and thus to additional nutrients exported to surface waters. Today, rainforests prevent the active erosion of soils and therefore the delivery of substantial fluvial nutrient supplies to the Gulf of Guinea.

\section{Material and methods}

\subsection{Stratigraphy of core KZAI-01}

Core KZAI-01 $\left(5^{\circ} 42.19^{\prime} \mathrm{S}, 11^{\circ} 14.01^{\prime} \mathrm{E} ; 816 \mathrm{~m}\right.$ water depth; $10.05 \mathrm{~m}$ length; Fig. 1) was recovered during the $1998 \mathrm{Za}-$ iAngo 1 cruise aboard the Atalante (Savoye, 1998).

The first published age model of core KZAI-01 (Bayon et al., 2012) was derived from seven accelerator mass spectrometry (AMS) ${ }^{14} \mathrm{C}$ dates on carbonates (bulk planktonic foraminifera or mixed marine carbonates; Table 1) and two age constraints obtained by tuning core KZAI-01 to core GeoB6518-1 (well-dated sedimentary record from the nearby area; Fig. 1) (Bayon et al., 2012). 


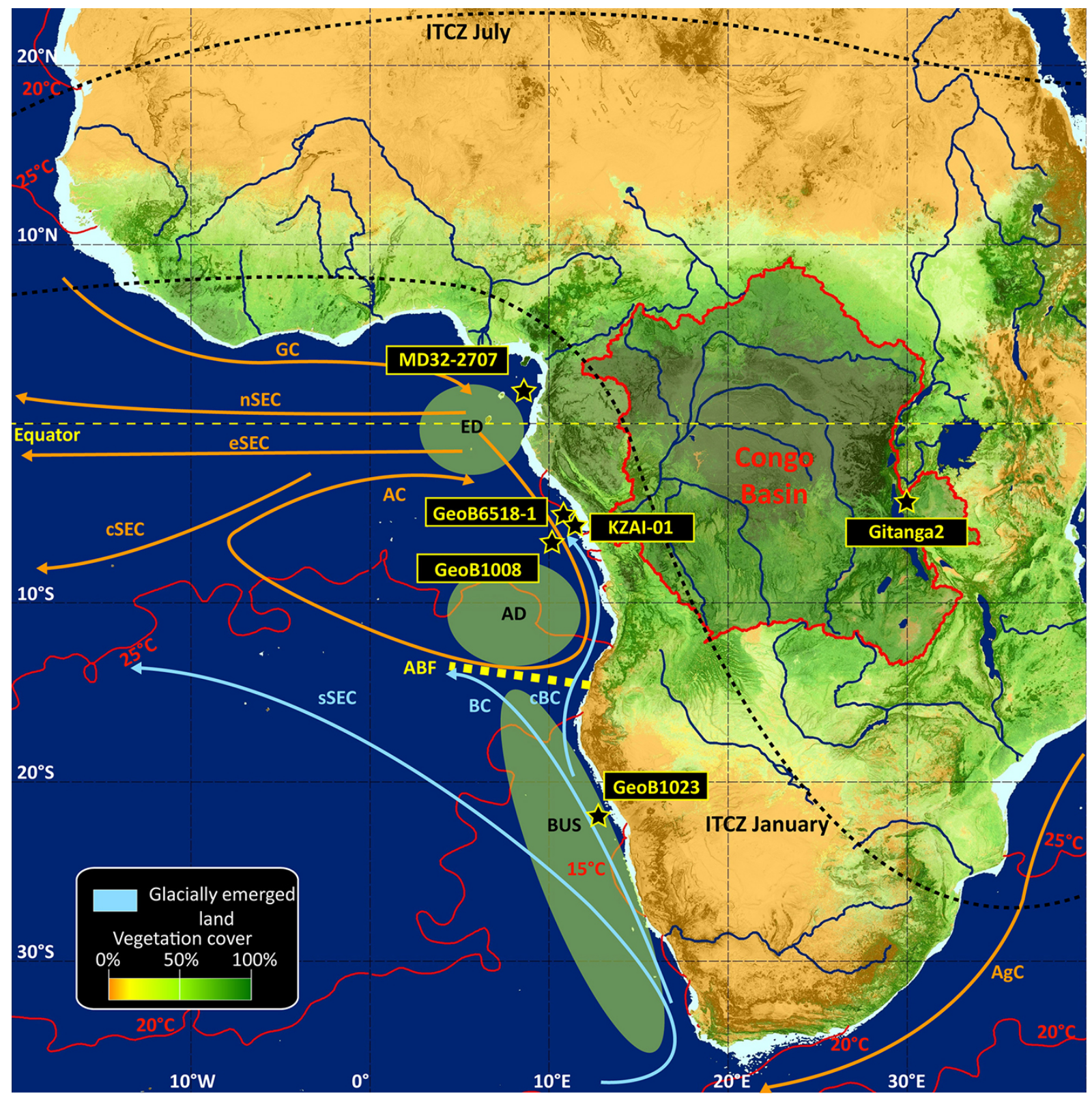

Figure 1. Map showing locations of the KZAI-01 core and other cores mentioned in the text: GeoB6518 (Schefuß et al., 2005; Bayon et al., 2012), GeoB1008 (Schneider et al., 1997), MD32-2707 (Weldeab et al., 2007), GeoB1023 (Shi et al., 1998) and GITANGA2 (Bonnefille and Chalié, 2000). The general pattern of present-day surface ocean currents of the adjacent Atlantic Ocean is extracted from Lass and Mohrholz (2008) and includes the Guinea Current (GC); the northern (nSEC), equatorial (eSEC), central (cSEC) and southern (sSEC) South Equatorial Current; the Angola Current (AC); the Angola-Benguela Front (ABF); the Benguela Current (BC); and the Agulhas Current $(\mathrm{AgC})$. Orange lines indicate warm currents and blue lines cold currents. Green zones correspond to upwelling zones (BUS: Benguela upwelling system) and oceanic domes (AD: Angola Dome; ED: equatorial dome; Voituriez, 1981; Lass and Mohrholz, 2008). Black dashed lines display mean seasonal locations of the ITCZ during July and January (Collier and Hughes, 2011). Red $5^{\circ} \mathrm{C}$ interval isolines correspond to annual mean SST (Hirahara et al., 2013). Vegetation cover (in \% per surface unity) is extracted from the Hansen et al. (2013) dataset.

In this study, three new $\mathrm{AMS}{ }^{14} \mathrm{C}$ dates on planktonic foraminifera and bivalves have been added between 370 and $620 \mathrm{~cm}$ (Table 1) in order to obtain a more robust stratigraphy for the last glacial period (Fig. 2). We have also added three new age constraints by tuning core KZAI-01 to nearby well-dated core GeoB6518-1 (AMS ${ }^{14} \mathrm{C}$ dates on monospecific foraminifera; Schefuß et al., 2005; Fig. 2). This enables us to strengthen the chronostratigraphy of the study core for the early Holocene as well as for the base of the KZAI-01 core, not constrained by AMS ${ }^{14} \mathrm{C}$ dates below $851 \mathrm{~cm}$. 
Table $1 .{ }^{14} \mathrm{C}$ dates obtained on the KZAI-01 core: 7 dates were previously obtained on marine carbonate material and 10 on bulk organic matter (Bayon et al., 2012), and 3 new dates have been added in this study. Two dates have been rejected (190 and $372 \mathrm{~cm}$ ) and displayed in italic, and dates acquired on bulk organic matter have not been considered for the establishment of the age model in this study (dates retained for the age model are given in bold in the Table).

\begin{tabular}{|c|c|c|c|c|c|}
\hline $\begin{array}{l}\text { Depth } \\
(\mathrm{cm})\end{array}$ & $\begin{array}{l}\text { Material } \\
\text { dated }\end{array}$ & $\begin{array}{l}\text { Laboratory } \\
\text { number }\end{array}$ & $\begin{array}{l}{ }^{14} \mathrm{C} \text { age } \\
(\mathrm{BP})\end{array}$ & $\begin{array}{l}\text { Mean } \\
\text { calibrated age } \\
\text { (cal BP) } \pm 2 \sigma \\
\text { range }\end{array}$ & Data origin \\
\hline 10 & $\begin{array}{l}\text { Mixed marine } \\
\text { carbonate }\end{array}$ & UtC-9311 & $2172 \pm 39$ & $1735 \pm 82$ & Bayon et al. (2012) \\
\hline 13 & $\begin{array}{l}\text { Bulk organic } \\
\text { matter }\end{array}$ & Poz-40293 & $1610 \pm 30$ & $1170 \pm 82$ & Bayon et al. (2012) \\
\hline 18 & $\begin{array}{l}\text { Bulk organic } \\
\text { matter }\end{array}$ & Poz-40295 & $2310 \pm 30$ & $1921 \pm 91$ & Bayon et al. (2012) \\
\hline 26 & $\begin{array}{l}\text { Bulk organic } \\
\text { matter }\end{array}$ & Poz-40296 & $2545 \pm 30$ & $2216 \pm 89$ & Bayon et al. (2012) \\
\hline 37 & $\begin{array}{l}\text { Bulk organic } \\
\text { matter }\end{array}$ & Poz-40297 & $3210 \pm 30$ & $3024 \pm 112$ & Bayon et al. (2012) \\
\hline 51 & $\begin{array}{l}\text { Bulk organic } \\
\text { matter }\end{array}$ & Poz-40298 & $3770 \pm 30$ & $3713 \pm 103$ & Bayon et al. (2012) \\
\hline 70 & $\begin{array}{l}\text { Bulk organic } \\
\text { matter }\end{array}$ & Poz-40299 & $4435 \pm 35$ & $4636 \pm 138$ & Bayon et al. (2012) \\
\hline 122 & $\begin{array}{l}\text { Bulk organic } \\
\text { matter }\end{array}$ & Poz-40300 & $5970 \pm 40$ & $6380 \pm 94$ & Bayon et al. (2012) \\
\hline 190 & $\begin{array}{l}\text { Mixed marine } \\
\text { carbonate }\end{array}$ & $U t C-9312$ & $8710 \pm 60$ & $9369 \pm 131$ & Bayon et al. (2012) \\
\hline 196 & $\begin{array}{l}\text { Bulk organic } \\
\text { matter }\end{array}$ & Poz-40301 & $8080 \pm 40$ & $8527 \pm 110$ & Bayon et al. (2012) \\
\hline 269 & $\begin{array}{l}\text { Bulk organic } \\
\text { matter }\end{array}$ & Poz-40302 & $9790 \pm 50$ & $10727 \pm 166$ & Bayon et al. (2012) \\
\hline 305 & $\begin{array}{l}\text { Bulk organic } \\
\text { matter }\end{array}$ & Poz-40389 & $10400 \pm 60$ & $11503 \pm 252$ & Bayon et al. (2012) \\
\hline 356 & $\begin{array}{l}\text { Planktonic } \\
\text { foraminifera }\end{array}$ & Poz-20108 & $10930 \pm 50$ & $12444 \pm 175$ & Bayon et al. (2012) \\
\hline 372 & Bivalve & Poz-73781 & $13450 \pm 70$ & $15598 \pm 276$ & This paper \\
\hline 456 & $\begin{array}{l}\text { Planktonic } \\
\text { foraminifera }\end{array}$ & Poz-20109 & $13950 \pm 70$ & $16328 \pm 251$ & Bayon et al. (2012) \\
\hline 522 & $\begin{array}{l}\text { Bolivina } \\
\text { spathulata }\end{array}$ & Poz-73782 & $20800 \pm 140$ & $24575 \pm 446$ & This paper \\
\hline 585 & $\begin{array}{l}\text { Planktonic } \\
\text { foraminifera }\end{array}$ & Poz-20110 & $23020 \pm 130$ & $27232 \pm 689$ & Bayon et al. (2012) \\
\hline 622 & Bivalve & Poz-73783 & $24870 \pm 200$ & $28454 \pm 447$ & This paper \\
\hline 678 & $\begin{array}{l}\text { Mixed marine } \\
\text { carbonate }\end{array}$ & UtC-9314 & $28240 \pm 280$ & $31812 \pm 668$ & Bayon et al. (2012) \\
\hline 851 & $\begin{array}{l}\text { Mixed marine } \\
\text { carbonate }\end{array}$ & UtC-9315 & $31800 \pm 400$ & $35274 \pm 405$ & Bayon et al. (2012) \\
\hline
\end{tabular}

All radiocarbon dates were calibrated to calendar ages with the Calib 7.0 program (Stuiver and Reimer, 1993) associated with a 400-year correction for the marine age reservoir (Reimer et al., 2013), and the final age model was built through linear regression between all stratigraphic pointers (Fig. 2). Mean calculated sedimentation rates are around $25 \mathrm{~cm} \mathrm{kyr}^{-1}$.

\subsection{Palynological analysis}

\subsubsection{Laboratory procedure for dinocyst extraction}

In this study, 203 samples were analysed for the period covering the last $44 \mathrm{kyr}$ with a $5 \mathrm{~cm}$ sampling interval (mean resolution analysis of about 200 years throughout the core, ranging between 20 and 800 years, according to the established age model). The preparation technique for palynolog- 

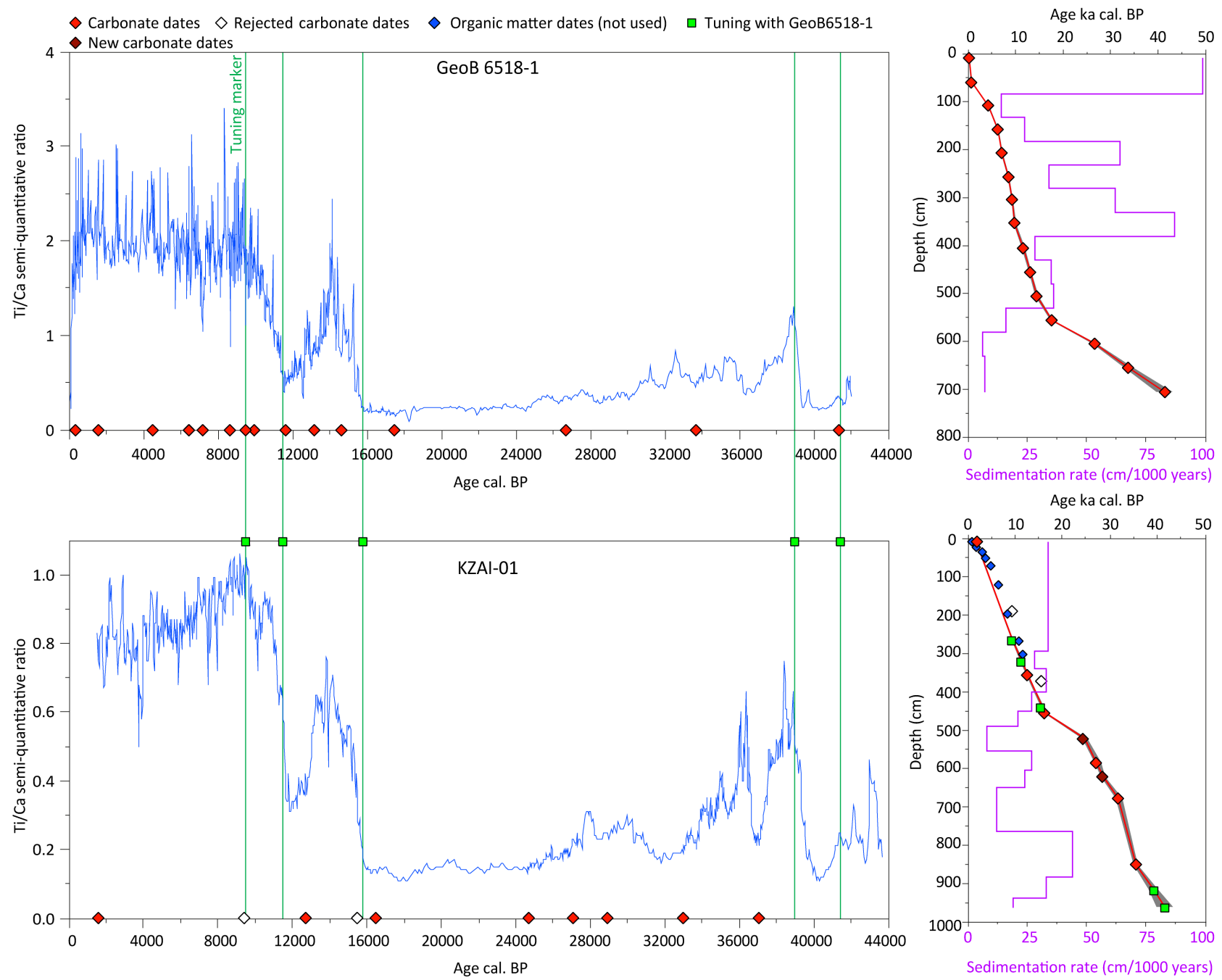

Figure 2. Age model established through a linear regression between retained AMS ${ }^{14} \mathrm{C}$ pointers (red squares; cf. Table 1). Blue squares correspond to ${ }^{14} \mathrm{C}$ dates acquired on organic matter (Bayon et al., 2012); not taken into account for the age model. Green squares correspond to dates obtained by tuning the KZAI-01 core with GeoB6518 core, on the basis on similar XRF Ti / Ca ratio trends. Grey band corresponds to the $2 \sigma$ range error of calibrated dates, and purple lines correspond to sedimentation rates $\left(\mathrm{cm} \mathrm{kyr}^{-1}\right)$.

ical analysis followed the procedure described in Marret et al. (2008). Calibrated tablets of known concentrations of $L y$ copodium clavatum spores were added to each sample before chemical treatments in order to estimate palynomorph concentrations (number of dinocysts per cubic centimetre of dry sediments), and chemical and physical treatments included cold $\mathrm{HCl}(10 \%)$, cold $\mathrm{HF}(40 \%)$ and sieving through a single-use $10 \mu \mathrm{m}$ nylon mesh screen. The final residue was mounted between slide and coverslip with glycerine jelly coloured with fuchsin. When the recommended number of 300 dinocysts could not be reached, a minimum of 100 specimens was counted on each sample (Fatela and Taborda, 2002), using a Leica DM 2500 microscope at $\times 630$ magnification. Fifteen samples, containing less than 100 specimens, were excluded from dinocyst results. Dinocyst concen- trations were based on the marker grain method (de Vernal et al., 1999), and dinocyst assemblages were described by the percentages of each species calculated on the basis of the total dinocyst sum, including unidentified taxa and excluding pre-Quaternary specimens. In addition to dinocyst counts, freshwater microalgae Pediastrum and Concentricystes were also identified and counted so as to discuss river discharge intensifications in parallel with our dinocyst data.

\subsubsection{Dinocysts as potential tracers for past primary productivity changes}

Palaeoproductivity regimes in the equatorial ocean could be inferred from our fossil assemblages thanks to the transfer function based on the modern analogue technique (MAT; Guiot and de Vernal, 2007) developed for the tropical At- 
lantic Ocean $(n=208$ modern analogues; Marret et al., 2008). A detailed discussion of limitations and pitfalls of inferring palaeoproductivity from dinocyst assemblages in the study area will be discussed in a separate paper. In the present study, we only focus on the dinoflagellate phytoplanktonic component through past dinocyst-specific observations. Indeed, among dinocyst assemblages, it is possible to distinguish between cysts formed by dinoflagellates with a strict nutritional strategy based on heterotrophy that we will refer to as "heterotrophic cysts" and other cysts formed by dinoflagellates for which the nutritional strategy can be complex, involving either autotrophy, heterotrophy or mixotrophy, and that we will refer as "non-heterotrophic cysts". Relative abundances of total heterotrophic cysts have previously been used as a signal for dinoflagellate primary productivity and indirectly for marine productivity, considering that heterotrophic dinoflagellates mainly feed on marine microorganisms including other dinoflagellates (whatever their nutritional strategies), diatoms and other microalgae (e.g. Zonneveld et al., 2013).

\section{Dinocyst results on core KZAI-01}

\subsection{Dinocyst concentrations}

A total of 53 dinocyst taxa (Supplement) have been identified in the studied samples, with an average of 15 taxa for each sample (Fig. 3). Dinocyst concentrations in sediments are generally very low, from 100 to 12000 cysts $\mathrm{cm}^{3}$ (Fig. 3). These low concentrations in the study area are thought to be caused by a strong dilution of the organic matter by terrigenous inputs (cf. Fig. 3) with a clear negative correlation between maximal values of terrestrial inputs ( $\mathrm{Ti} / \mathrm{Ca}$ and minimal values of dinocyst concentrations) and also a probable competition with diatom productivity (Marret et al., 2008).

Higher cyst concentrations are recorded between 850 and $450 \mathrm{~cm}\left(37.5-15.5 \mathrm{ka}\right.$ BP; mean value of $\left.3000 \mathrm{cysts} \mathrm{cm}^{-3}\right)$, as well as between 90 and $30 \mathrm{~cm} \mathrm{(4-2.4} \mathrm{ka} \mathrm{BP;} \mathrm{mean} \mathrm{value}$ of $6000 \mathrm{cysts}^{3}$ ), for which two maxima are observed with 10900 and 11200 cysts $\mathrm{cm}^{-3}$, respectively (Fig. 3). Increases in dinocyst concentrations are due to increasing occurrences of Operculodinium centrocarpum or Lingulodinium machaerophorum (Fig. 3). Heterotrophic cyst concentrations (mainly led by Brigantedinium spp. and Echinidinium species; Fig. 3) as well as other cyst concentrations reach their maximal values during the same main interval, i.e between 850 and $450 \mathrm{~cm}$ but are 3 times lower for heterotrophs (Fig. 3). Higher abundance of heterotrophic cysts, mainly driven by Brigantedinium spp. percentages all along the record (Fig. 3), as well as those of Echinidinium spp. between 450 and $90 \mathrm{~cm}$ (15.5-4 ka BP; Figs. 3 and 5), are strongly correlated with lower dinocyst concentrations, especially between 15 and $4 \mathrm{kaBP}$ (Figs. 3 and 4). This could be consistent with the fact that diatoms as well as dinoflag- ellates are the main food for strictly heterotrophic dinoflagellates (Marret and Zonneveld, 2003), therefore echoing the previous idea of a competition between dinoflagellate and diatom phytoplanktonic productivity in the study area (Marret and Zonneveld, 2003).

Even if heterotrophic dinocyst concentrations can firstly be attributed to dilution or concentration processes in sediments, the transition between generally higher cyst concentrations and lower ones observed at $450 \mathrm{~cm}(15.5 \pm 0.4 \mathrm{ka} \mathrm{BP})$ is synchronous with a marked shift in biogenic opal $\left(\mathrm{BiSiO}_{2}\right)$ and total organic carbon (TOC) observed in a nearby core (Schneider et al., 1997). This suggests different marine productivity patterns before and after $15.5 \pm 0.4 \mathrm{kaBP}$. Based at least on the fact that these data indicate generally similar trends, an atypical pattern is observed at $90 \mathrm{~cm}$. While heterotrophic concentrations remain low, and despite a relative stable trend characterized by still high terrigenous inputs (Bayon et al., 2012; Fig. 3) as well as low $\mathrm{BiSiO}_{2}$ and TOC values (Schneider et al., 1997), total dinocyst concentrations reach their maximum. To understand this atypical dinocyst concentration signal, indexes of specific diversity and dominance have been calculated to discuss periods possibly characterized by cyst advection (positive correlation between dominance and diversity) and in situ dinoflagellate productivity (negative correlation between dominance and diversity). Here, signals remain roughly anti-correlated all over the core, except at $90 \mathrm{~cm}$ (Fig. 3), possibly due to a massive advection of $O$. centrocarpum at that time (Fig. 3).

\subsection{Dinocyst assemblages}

Based on variations in cyst concentrations and in relative abundances of major species, five palynozones (A, B, C, D, E; Fig. 3) have been visually established and then subdivided into several sub-palynozones (1, 2, 3; Figs. 4 and 5) based on the rest of the assemblage (minor species always observed with at least $>2 \%$; Figs. 4 and 5).

Temporal successions between dinocyst species can be observed all along the core, in particular for the dinocyst group mainly controlled by sea-surface salinity (Marret and Zonneveld, 2003), including Spiniferites ramosus, $\mathrm{Ne}$ matosphaeropsis labyrinthus, L. machaerophorum, O. centrocarpum and Operculodinium israelianum (Figs. 3, 4), as well as Echinidinium spp. (Fig. 5). The first important succession occurred at $37.5 \pm 0.7 \mathrm{ka} \mathrm{BP}$ (limit between palynozones $\mathrm{E}$ and $\mathrm{D}$ ), with a significant drop in the maximal relative abundances of $S$. ramosus and $N$. labyrinthus, then followed by maximal relative abundances of $L$. machaerophorum (Fig. 4). At $32 \pm 0.7 \mathrm{ka} \mathrm{BP}$ (limit between palynozones $\mathrm{D}$ and $\mathrm{C}$ ), a second major transition is related to a strong decline in L. machaerophorum synchronously with maximal percentages of $O$. centrocarpum and then accompanied by $O$. israelianum across the whole palynozone C (Fig. 4). A third succession (limit between palynozone $\mathrm{C}$ and $\mathrm{B}$ ) is then observed between $O$. centrocarpum and Echinidinium spp. 


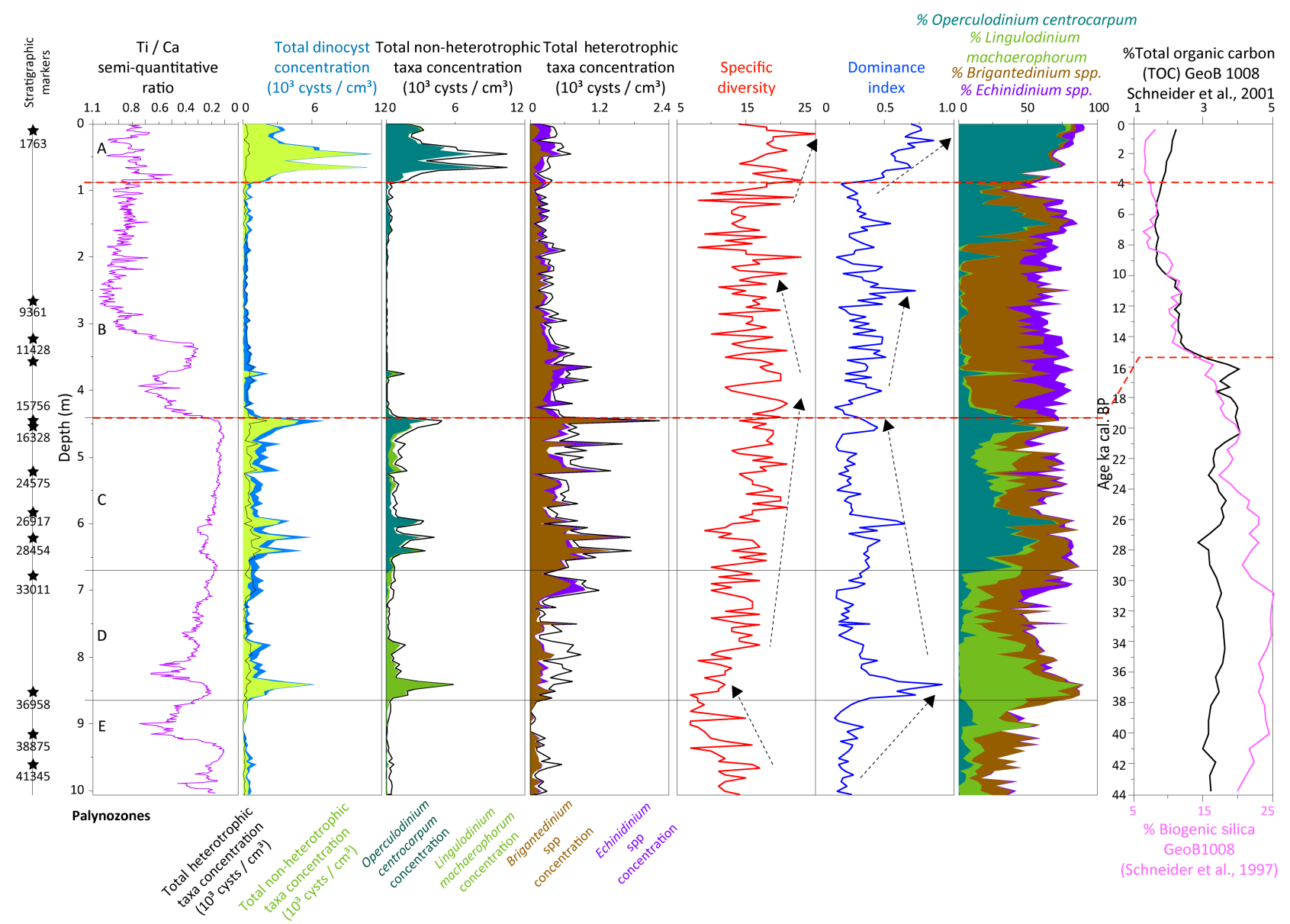

Figure 3. Comparison between total dinocyst concentrations (cysts $\mathrm{cm}^{-3}$ ), non-heterotrophic cyst concentrations, as well as Lingulodinium machaerophorum and Operculodinium centrocarpum concentrations, both species being mainly responsible for total cyst concentrations in the study core. Same approach for heterotrophic taxa: comparison between total heterotrophic concentrations in parallel with Brigantedinium spp. and Echinidinium spp., both taxa being mainly responsible for total heterotrophic concentrations in the study core. Above-mentioned species are also represented in cumulated percentages. To discuss relationships between primary productivity, dinocyst concentrations and terrigenous dilution, the XRF Ti / Ca ratio of core KZAI-01 is displayed in parallel with biogenic opal and total organic matter signals extracted from core GeoB1008 (Schneider et al., 1997). Also, specific diversity and dominance indexes enable discussing the potential advection of dinocysts in the study. Red dashed lines correspond to major transitions in total dinocyst concentrations allowing us to define five major palynozones (A, B, C, D, E).

(Figs. 4 and 5) at $15.5 \pm 0.4 \mathrm{ka} \mathrm{BP}$, while the last major transition (limit B-A) evidences the important decline in Brigantedinium spp. and strong reincrease in $O$. centrocarpum from $6 \mathrm{ka}$ BP onwards, together with the significant occurrence of Spiniferites pachydermus near the start of palynozone A (a2, Fig. 4).

Among the non-heterotrophs, the group of thermophile species comprises Impagidinium aculeatum, Impagidinium patulum, Spiniferites bentorii, Tuberculodinium vancampoae, Spiniferites membranaceus and S. pachydermus. This group also shows clear temporal successions across the different palynozones (cf. Fig. 4), in particular S. pachyder$m u s$ at the start of palynozone A (Fig. 4). With regards to Operculodinium aguinawense (Fig. 4), the southernmost oc- currences ever recorded of this species is observed in core KZAI-01. Today, this species only occurs off the coasts of Cameroon and eastern Nigeria, in a small area encompassing GeoB4905 core (Fig. 6; Marret and Kim, 2009). Over the last $15.5 \pm 0.4 \mathrm{kyr}$, variations of $O$. aguinawense percentages are relatively well correlated with the ones of Spiniferites mirabilis, in particular across the last deglaciation. Today, both species are restricted to the same area along the north equatorial African coast (Fig. 6; Zonneveld et al., 2013).

Among the heterotrophs, neritic taxa such as cysts of P. schwartzii, Selenopemphix nephroides and especially Xandarodinium xanthum as well as Quinquecuspis concreta (Fig. 5) show extremely close occurrences all along the core. This is especially obvious between $37 \pm 0.7$ and 


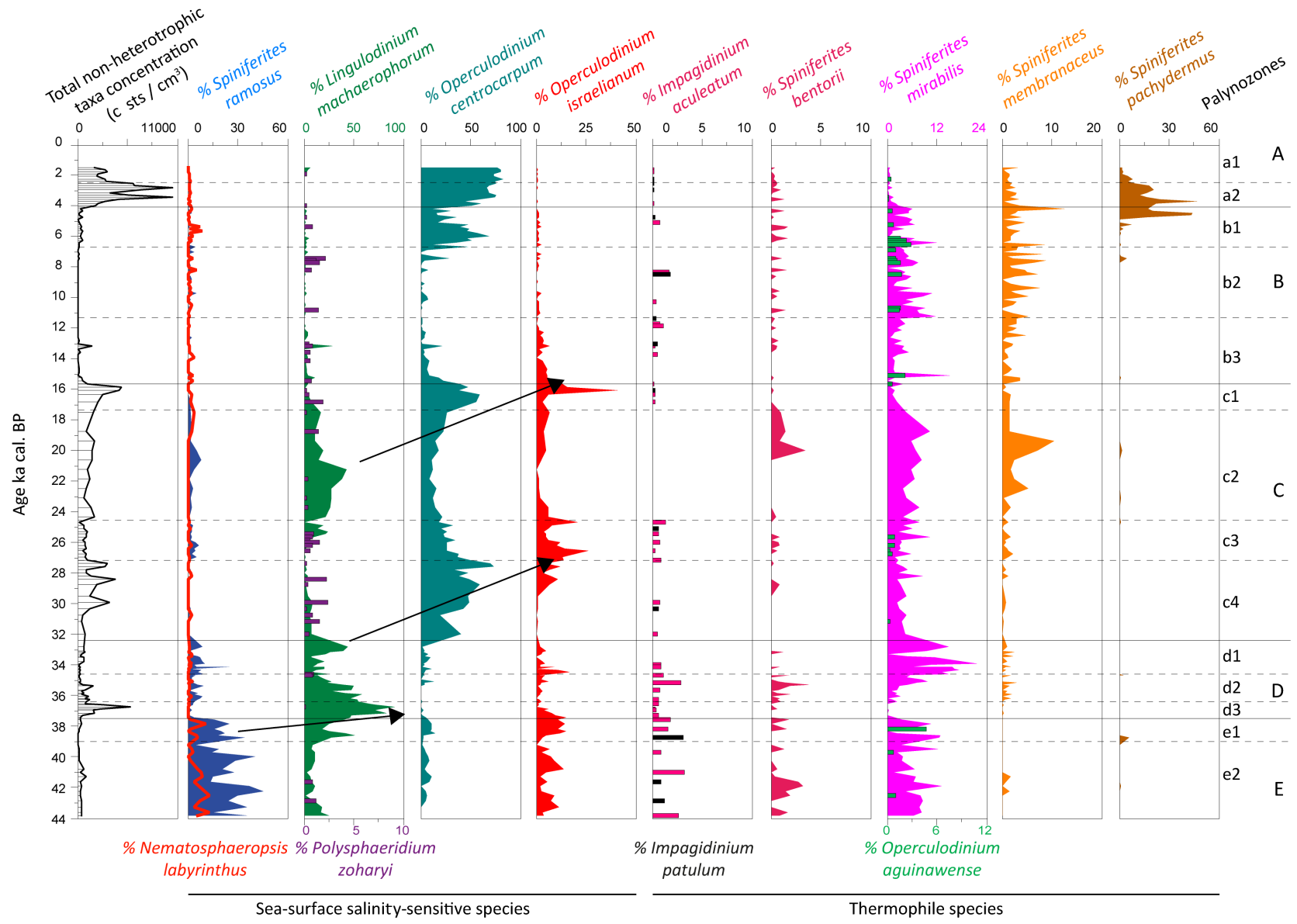

Figure 4. Selection of major ( $>2 \%$ ) non-heterotrophic dinocyst species represented in percentages, in parallel with total non-heterotrophic cyst concentrations $\left(\right.$ cysts $\mathrm{cm}^{-3}$ ). Some species have been grouped: Spiniferites ramosus also includes Spiniferites bulloides, and Nematosphaeropsis labyrinthus also includes Nematosphaeropsis lemniscata. Palynozones (A to E) have been established according to major variations in absolute cyst concentrations (cf. Fig. 3), and minor subdivisions (Ax to Ex) have been delimited thanks to whole dinocyst assemblages in percentages (cf. Figs. 4 and 5). Species are here classified according to observed temporal successions indicated by black arrows.

$7 \pm 0.2 \mathrm{kaBP}$ (Fig. 5), and maximal percentages of these species are recorded around 36-32, 25-20 and 15.5-7 ka BP (Fig. 5). Also, another important feature is the disappearance of cysts of $P$. schwartzii around $35 \pm 0.4 \mathrm{kaBP}$, synchronously with a significant increase in $S$. nephroides at that time (Fig. 5; limit between sub-palynozones d2 and d1).

\section{Discussion}

\subsection{Orbital control on past dinoflagellate productivity regimes}

\subsubsection{Dinoflagellate productivity on the Congolese margin: Congo River versus upwelling dynamics}

It is commonly accepted (Dupont et al., 1998; Shi et al., 1998; Dupont and Behling, 2006; Kim et al., 2010; Zonneveld et al., 2013) that in the intertropical band higher pri- mary productivity occurred over the last glacial cycle during periods of global cooling such as the Last Glacial Maximum (LGM) or Greenland Stadials (GSs, including Heinrich Stadials or HSs), in response to intensified upwelling cells. Inversely, during warmer and wetter periods such as Greenland Interstadials (GIs) or the Holocene, characterized by higher riverine inputs, primary productivity is low.

Within our dinocyst record, higher dinoflagellate productivity seems to be recorded during the last glacial until $15.5 \pm 0.4 \mathrm{ka} \mathrm{BP}$ (high cyst concentrations), consistently with high values of $\mathrm{BiSiO}_{2}$ and TOC observed in the neighbouring core GeoB 1008 (Schneider et al., 1997; Fig. 3). Furthermore, Trinovantedinium applanatum, a typical wellknown coastal upwelling species (Marret and Zonneveld, 2003), mainly occurred between $28 \pm 0.6$ and $19 \pm 0.3 \mathrm{ka} \mathrm{BP}$ (palynozones c3 to c2; Figs. 5 and 7), consistently with the idea of stronger upwelling cells across glacial maxima, and more specifically here during Marine Isotopic Stage (MIS) 2 


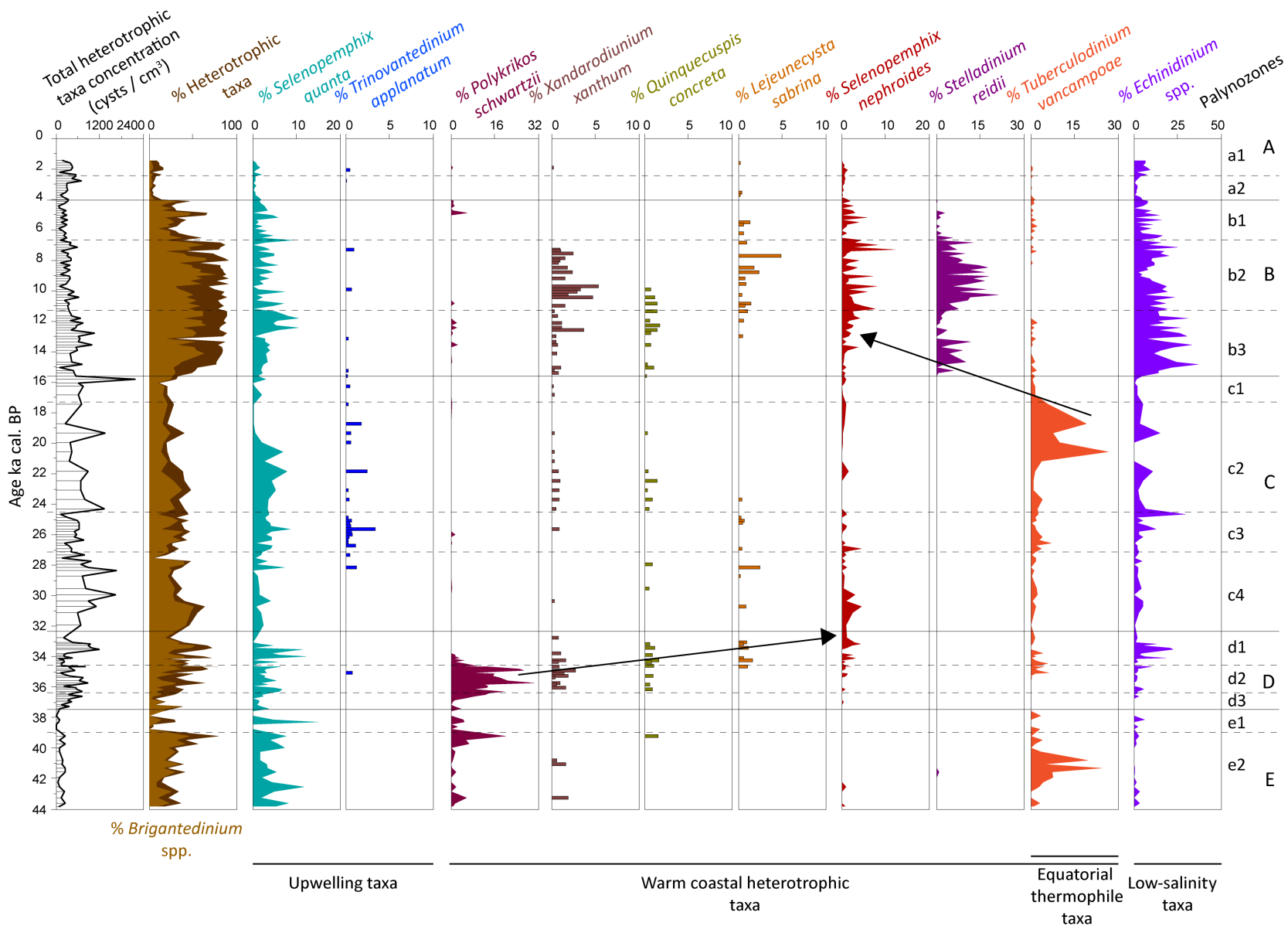

Figure 5. Selection of major $(>2 \%)$ heterotrophic dinocyst species represented in percentages, in parallel with total heterotrophic cyst concentrations (cysts $\mathrm{cm}^{-3}$ ). Echinidinium spp. includes E. aculeatum, E. delicatum, E. granulatum and E. transparantum. Lingulodinium machaerophorum is displayed with Echinidinium spp. according to their river-plume affinity. Palynozones (A to E) have been established according to major variations in absolute cyst concentrations (cf. Fig. 3), and minor subdivisions (Ax to Ex) have been delimited thanks to whole dinocyst assemblages in percentages (cf. Figs. 4 and 5). Species are here classified according to observed temporal successions indicated by black arrows.

in a dry context characterized by weak terrigenous supplies to the Congo margin, and cold sea-surface conditions (Figs. 4 and 6).

At the onset of the last deglaciation, around $15.5 \pm 0.4 \mathrm{ka} \mathrm{BP}$, a quasi-disappearance of the T. applanatum signal is observed (Figs. 5 and 7). However, heterotrophic percentages remain high and are even characterized, between $15.5 \pm 0.4$ and $7 \pm 0.2 \mathrm{kaBP}$ (sub-palynozones b2 and b3), by the highest values ever recorded (Figs. 5 and 7). This leads us to consider, at that time, another major source of nutrients to the ocean other than upwelling cells. The relatively good consistency between major element terrestrial signals (cf. X-ray fluorescence (XRF) ratios in the KZAI-01 core), percentages of heterotrophic (Brigantedinium spp.) and fluvial-sensitive cysts (Echinidinium spp., river-plume taxa) (Figs. 5 and 7) suggests that nutrient-rich freshwater discharges from the Congo River probably acted as a major driving factor for promoting dinoflagellate productivity in the study area, especially across the last deglaciation but also during MIS 3. Furthermore, between $15.5 \pm 0.4$ and $7 \pm 0.2 \mathrm{kaBP}$, continental shelf reworking, induced by the post-glacial sea-level rise, may have also represented an additional source of nutrients to the ocean (Marret et al., 2008), also contributing to slightly enhanced dinoflagellate productivity at that time (Figs. 5 and 7).

\subsubsection{Precession versus obliquity accounting for different fluvial regimes}

The influence of orbital forcing on low-latitude atmospheric processes is still a matter of debate. The tropical response to obliquity forcing appears to be the remote influence of high-latitude glacial ice-sheet oscillations (deMenocal et al., 1993), in parallel with significant changes in cross-equatorial insolation gradient (Bosmans et al., 2015). Precession forc- 


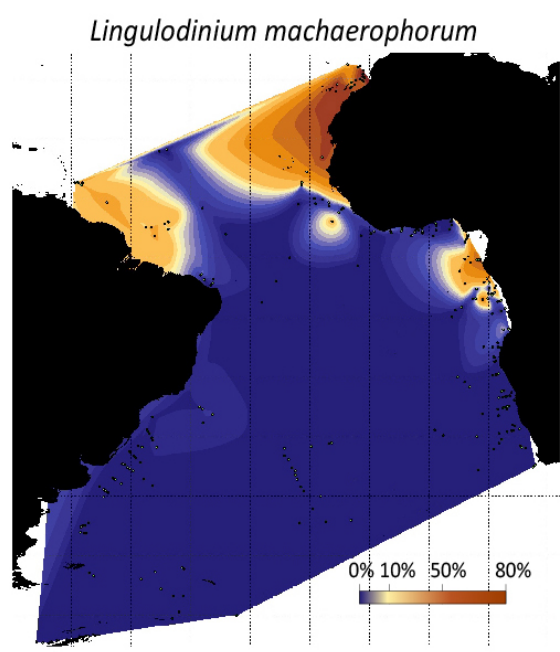

Tuberculodinium vancampoae

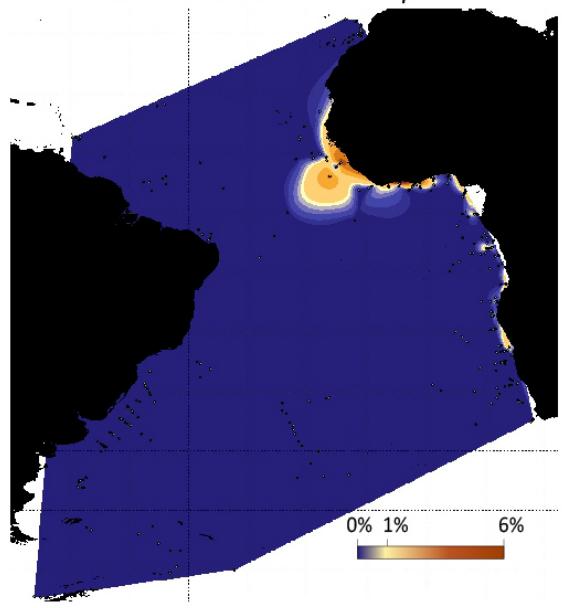

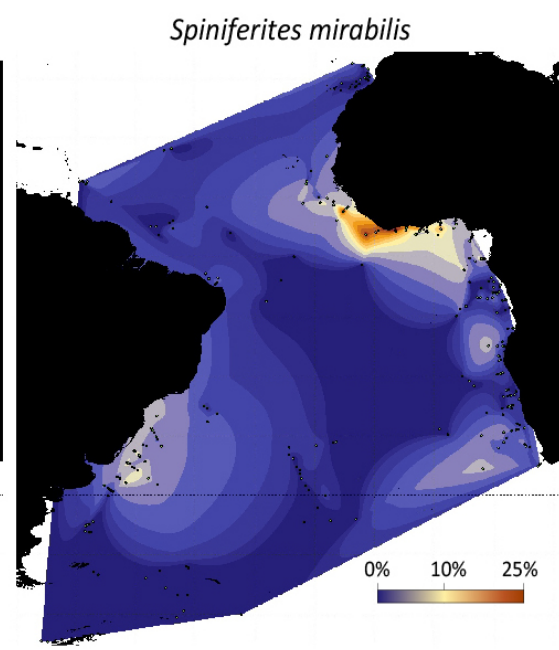

Operculodinium aguinawense

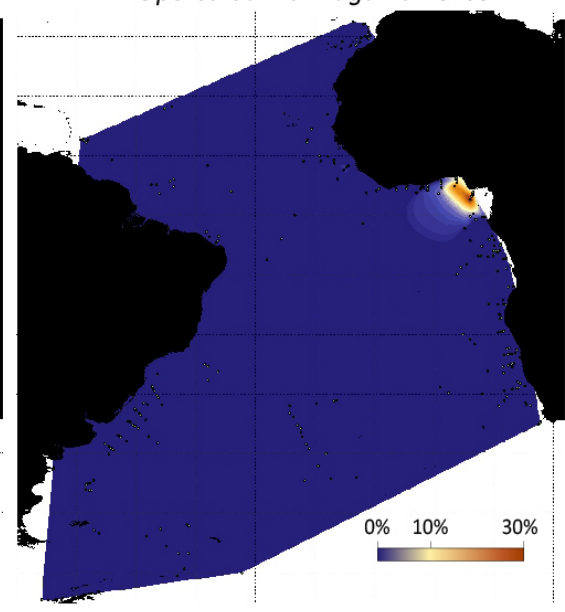

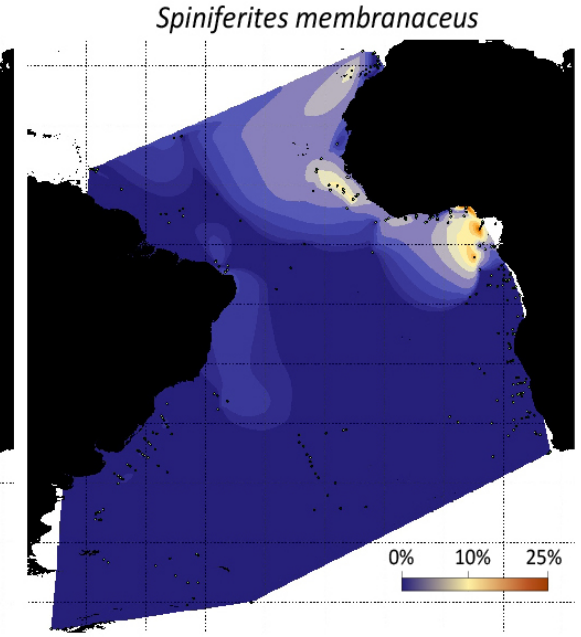

Operculodinium centrocarpum

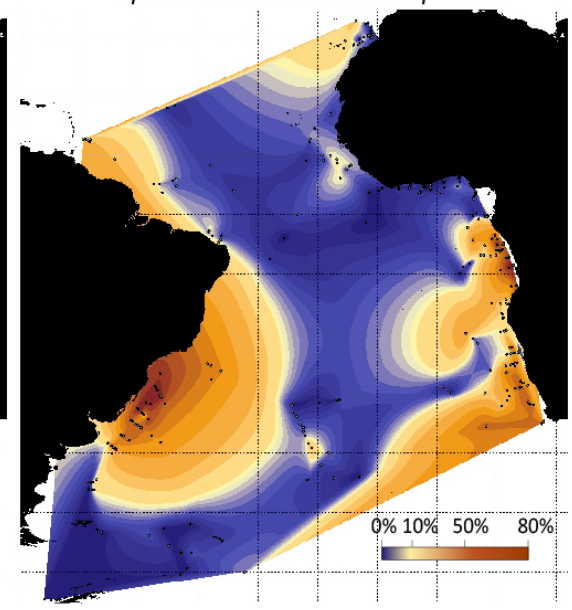

Figure 6. Present-day distribution of selected dinocyst taxa among major ones discussed in the paper. Percentages from 277 sites are extracted from the modern dinocyst atlas (Marret et al., 2008; Zonneveld et al., 2013).

ing is more important in low-latitude moisture changes, i.e warmer and wetter conditions in the hemisphere where summer solstice occurred at the Earth perihelion (Merlis et al., 2012). Furthermore, it has been inferred that the precession/obliquity combination also has a great influence on monsoon oscillations with a significant prevalence of the precession forcing (Tuenter et al., 2003). More precisely, minima of precession would correspond to an intensification of the monsoonal activity, and obliquity would tend to mitigate (minima of obliquity) or enhance (maxima of obliquity) the initial precession forcing (Tuenter et al., 2003). The orbital variations have therefore significantly changed the latitudinal spread of precipitation in consequence of oceanic heat gradient variations (Stager et al., 2011; McGee et al., 2014).

In our dinocyst record, significant occurrences of fluvialsensitive cysts (especially L. machaerophorum and Echinidinium spp.) appear to correspond to minima of precession, thus suggesting wetter conditions in the study area (Fig. 7). This is observed especially during the last deglaciation - the early Holocene between $15.5 \pm 0.4$ and $4 \pm 0.15 \mathrm{kaBP}$ (with the prevalence of Echinidinium spp.) - as well as during the MIS 3 interval between $39 \pm 0.9$ and $32 \pm 0.7 \mathrm{ka} \mathrm{BP}$ (with the prevalence of L. machaerophorum). Superimposed on this general pattern, a combination of "minimum of precession - maximum of obliquity" would explain the optimal orbital combination for high-moisture conditions according to Tuenter et al. (2003). This configuration did indeed occur between 16 and $6 \mathrm{kaBP}$ in our dinocyst results and corresponds to the maximal recorded values of fluvialsensitive cysts (Echinidinium spp.) in combination with the highest values of heterotrophic cyst percentages (mainly including Brigantedinium spp.) (Fig. 7).

The minimum of precession recorded during MIS 3 (Fig. 7) is characterized by a decreasing trend of Earth's obliquity and is also consistently characterized by a weaker $\mathrm{Ti} / \mathrm{Ca}$ ratio and associated lower surface productivities between $39 \pm 0.9$ and $32 \pm 0.7 \mathrm{kaBP}$ (Fig. 7). Despite the austral location of the KZAI-01 core, dinocyst assemblages indi- 


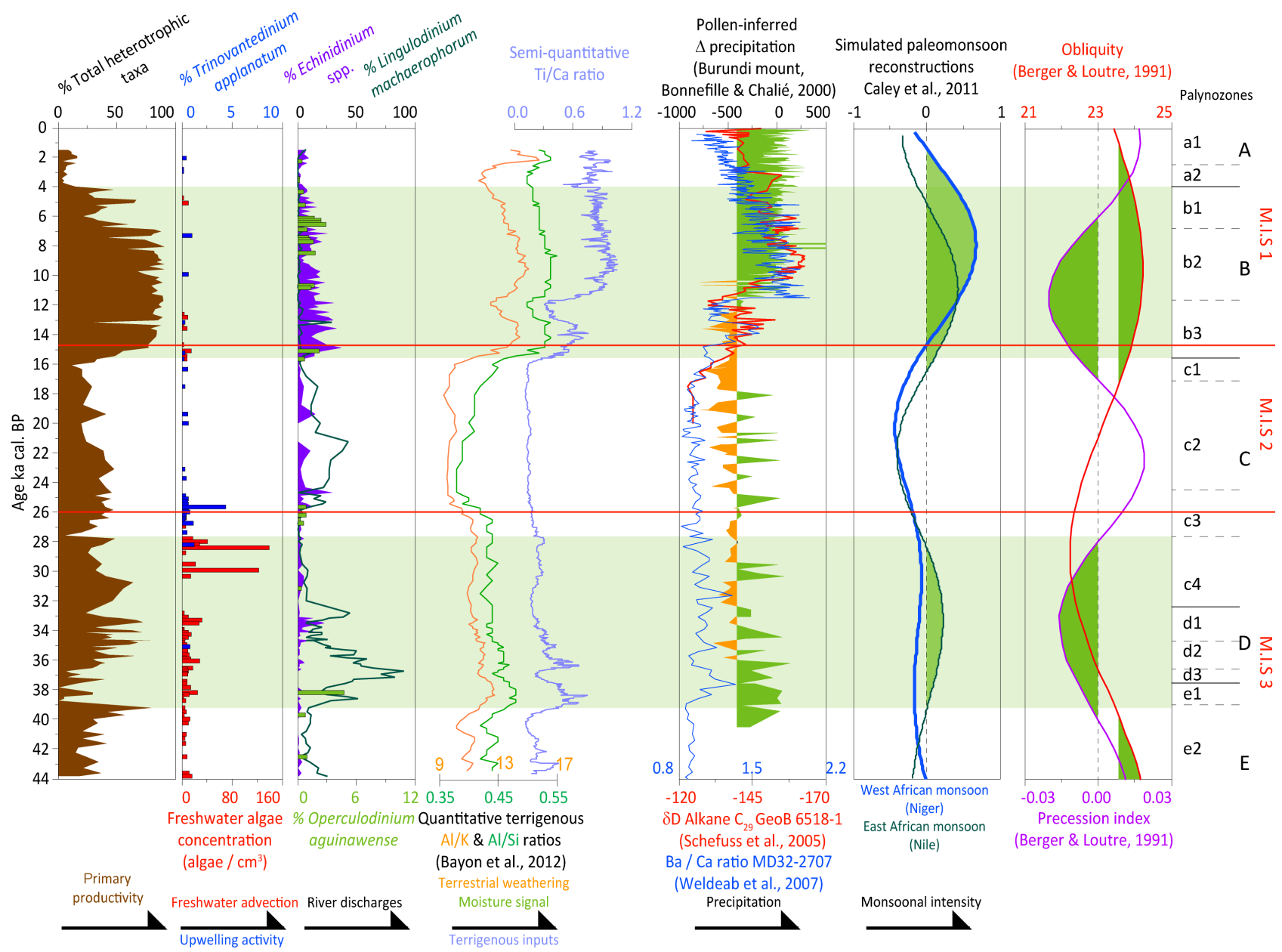

Figure 7. Comparison between total heterotrophic cyst abundances and Trinovantedinium applanatum percentages, both accounting for upwelling activity (Marret and Zonneveld, 2003). River-plume taxa: Echinidinium spp. and Lingulodinium machaerophorum as well as coenobia of freshwater microalgae Pediastrum and terrigenous signals (XRF Ti / Ca ratio, quantitative measurements of major elements $\mathrm{Al} / \mathrm{K}$ and $\mathrm{Al}$ / Si; Bayon et al., 2012). This allows discussing Congo River discharges. Relationships between river discharges and palaeomonsoons are displayed through (i) pollen-inferred rainfall anomalies in Burundi mountains (Bonnefille and Chalié, 2000: the threshold with positive anomalies in green and negative anomalies in orange is calculated from mean glacial values) in parallel with $\delta D$ on alkane $\mathrm{C}_{29}$ (core GeoB6518; Schefuß) displayed in red, (ii) regional-scale monsoon reconstructions (western and eastern African monsoons; Caley et al., 2011: maximal monsoon regimes are underlined in green), and (iii) Globigerinoides ruber Ba / Ca ratio obtained from core MD32-2707 (Weldeab et al., 2007). Orbital parameters such as the obliquity and the precession (Berger and Loutre, 1991) are also displayed, with precession minima and obliquity maxima highlighted in green. Green bands correspond to major orbital-scale moisture conditions discussed in the paper.

cate wetter conditions during precession minima (Fig. 7), i.e when Earth's perihelion occurred during the northern summer solstice, with associated drier conditions in the Southern Hemisphere (Merlis et al., 2012). Conversely, maxima of precession, supposed to be favourable for wetter conditions in the Southern Hemisphere, correspond to periods with lower terrigenous inputs, especially between $44 \pm 1.6$ and $39 \pm 0.9 \mathrm{kaBP}$ (subpalynozone e2) and between $25 \pm 0.5$ and $16 \pm 0.2 \mathrm{ka} \mathrm{BP}$ (subpalynozones c2 and c1; Fig. 7).

\subsubsection{The atypical signature of MIS 2}

In the tropics, during MIS 2, the latitudinal contraction of the TR resulted in colder conditions on the continent (Powers et al., 2005; Tierney et al., 2011; Loomis et al., 2012) with the establishment of open landscape (Anhuf et al., 2006) and cold surface waters (deMenocal et al., 2000; Weldeab et al., 2005; Shakun and Carlson, 2010). This widely observed pattern is in agreement with the low terrigenous signal recorded on core KZAI-01 (Fig. 7) that suggests reduced weathering conditions combined with lower terrestrial erosion at that time. Palaeoprecipitation reconstructions (Bon- 
nefille and Chalié, 2000) also suggest generally low values in the Congo Basin, characterized however by a complex pattern oscillating between slightly wetter and drier conditions. In our dinocyst record, low occurrences of T. applanatum, Selenopemphix quanta (Fig. 5) and cysts of Pentapharsodinium dalei (Appendix) are consistent with the tropical glacial period, mainly influenced by upwelling dynamics under dry climate.

However, between $25 \pm 0.5$ and $17 \pm 0.25 \mathrm{kaBP}$ (subpalynozones c2 and c3; Fig. 7), low relative abundances of Echinidinium spp. as well as high percentages of $L$. machaerophorum (up to 50\%) would suggest strengthened river discharges and thus wetter conditions consistent with the general pattern of austral moisture during maximal values of the precession index. Even if an influence of lower sea level on the neritic ecology of both Echinidinium spp. and L. Machaerophorum during this time cannot be ruled out entirely, this pattern can possibly be explained by the cross-equatorial location of the Congo Basin, therefore benefiting from Southern Hemisphere wetter configurations, the northern Congo Basin corresponding to a third of the whole surface. However, northern tributary rivers contribute half the total discharge (Bultot, 1971; Lempicka, 1971), and it is important to note the generally greater influence of northern rivers in comparison with austral ones within the Congo Basin. Terrigenous inputs to the ocean will then remain more important when the northern basin will be fed by strengthened precipitation in a boreal context of precession minima.

Another atypical dinocyst signature of MIS 2 is based on the occurrence of thermophile species (S. mirabilis, S. membranaceus, $S$. bentorii and $T$. vancampoae), currently found in equatorial warm waters (Fig. 6), which mainly occurred between $21 \pm 0.4$ and $17 \pm 0.25 \mathrm{kaBP}$, after a gradual increase noted from the beginning of the LGM (Figs. 4 and 5). The southward shift of the TR and the equatorial warm waters until $2^{\circ} \mathrm{S}$ (Arbuszewsky et al., 2013) may have brought heat and moisture to the study area while other parts of the equatorial Atlantic remained colder and drier (Stager et al., 2011). Furthermore, the world atlas of modern dinocysts (Zonneveld et al., 2013) also describes these thermophile species as being oligotrophic to mesotrophic. Their occurrences during MIS 2 could thus suggest such conditions in the study area, consistently with recorded lower terrigenous inputs during this period (Figs. 3 and 7), while high percentages of heterotrophic taxa (up to $40 \%$ of dinocyst assemblages during MIS 2, especially coastal warm heterotrophic taxa) would rather evidence mesotrophic conditions during this interval, consistent with present-day trophic conditions characterizing coastal equatorial waters.

\subsubsection{Eastern and western African monsoons: complex interferences in the Congo Basin}

The large area of the Congo Basin raises the question of the complex interferences between western and eastern African monsoon systems. The atmosphere above the catchment area is indeed divided by the Congo Air Boundary (CAB) convergence zone (Tierney et al., 2011), delineating the border between the western and eastern African monsoons. Past oscillations of these different monsoon clusters have been simulated (Caley et al., 2011; Fig. 7) from palaeo-river discharges of the Niger (western African monsoon) and of the Nile (eastern African monsoon) and have also been reconstructed through $\mathrm{Ba} / \mathrm{Ca}$ ratios of Globigerinoides ruber (MD32-2707 core; Figs. 1 and 7; Weldeab et al., 2007). As mentioned above, dinocyst river-plume assemblages of the KZAI-01 core strongly develop in response to boreal summer river discharges linked with precession minima (Fig. 7), suggesting that the western African monsoon can be considered as the main forcing for northern summer rainfalls in the Congo Basin. This common pattern is particularly well highlighted during the last deglaciation, when relative abundances of river-plume taxa increase in parallel with terrigenous signals shortly after the increase in the western African monsoon, around $16 \pm 0.2 \mathrm{kaBP}$ (Fig. 7). Furthermore, the maximum of the west African monsoon activity between 8 and $6 \mathrm{kaBP}$ (Fig. 7) also corresponds to the highest occurrences of $O$. aguinawense, evidencing a great relationship between the western African monsoonal forcing and the establishment of near-equatorial conditions during this period (cf. Fig. 6; Marret and Kim, 2009).

However, the relationship described above between western African monsoon signal and dinocyst assemblages is less clear during the recorded wetter interval ranging from $39 \pm 0.9$ to $27.5 \pm 0.7 \mathrm{kaBP}$ (Fig. 7). Our dinocyst data would indeed suggest a better correlation with the maximum of the eastern African monsoon signal (Fig. 7) while the western one remained weakened. This pattern is well correlated with estimates of palaeoprecipitation inferred from pollen extracted from Burundi mounts (Bonnefille and Chalié, 2000), which display higher precipitation during this interval, also in accordance with strengthened eastern African monsoons (Fig. 7).

\subsection{Suborbital variations over the last $20 \mathrm{kyr}$}

\subsubsection{The last deglaciation}

\section{The tropical response of Heinrich Stadial 1 (HS1)}

Between $18 \pm 0.3$ and $15.5 \pm 0.4 \mathrm{kaBP}$, relative abundances of thermophile and river-plume species dropped sharply while $O$. centrocarpum reached very high percentages (up to $50 \%$ ) at that time (sub-palynozone c1; Fig. 8). The presentday distribution of $O$. centrocarpum in the south Atlantic Ocean shows a strong relationship with northward cold currents (including the BC) (Fig. 6; Zonneveld et al., 2013), especially during the austral winter when cold currents reach the equatorial area. High percentages of $O$. centrocarpum may thus suggest a greater influence of the $\mathrm{BC}$ advection in 
our study area between 18 and $15.5 \mathrm{kaBP}$. The increase in $O$. centrocarpum percentages is also noticeable within the Benguela upwelling system (GeoB1023 core; Figs. 1 and 8; Shi et al., 1998), also highlighting the BC activity on a larger regional scale. Combined with occurrences of T. applanatum at that time (Fig. 8), which today is typical of the modern Benguela upwelling system along the Angolan margin (Holzwarth et al., 2000; Zonneveld et al., 2013), both species would thus indicate a cold and dry climate, consistent with previous studies that described a strong drought on the African continent (Stager et al., 2002, 2011; Bouimetarhan et al., 2012; Weldeab, 2012). More precisely, low precipitation (Bonnefille and Chalié, 2000; Schefuß et al., 2005; Fig. 7) was recorded as well as a continental and marine cooling ranging between 1 and $2{ }^{\circ} \mathrm{C}$ below mean LGM values (Müller et al., 1998; Powers et al., 2005; Weldeab et al., 2005, 2007; Loomis et al., 2012).

This cool and dry event appears synchronous with a massive advection of freshwater that occurred in the North Atlantic during HS1. The tropical response of HS1 would then consist of a southward shift of the TR (Arbuszewski et al., 2013; McGee et al., 2014), involving a contraction of the latitudinal belts (Stager et al., 2011) and weakened monsoons during this period. It is interesting to note that while dinocysts suggest a marked sea-surface cooling, isotopic signals from nearby core GeoB6518-1 (Schefuß et al., 2005; Fig. 8) suggest a steady increase in tropical moisture during HS1. This implies a fundamental divergence between marine and continental compartments across the last deglaciation.

\section{The equatorial signal of increasing deglacial warming at 15.5 ka BP}

Around 15.5-15 ka BP, the equatorial deglacial transition occurred in parallel with a global warming (Weldeab et al., 2005; Weijers et al., 2007; Leduc et al., 2010), linked with the Northern Hemisphere July insolation increase. This resulted in a northward shift of the TR (Arbuszewski et al., 2013; McGee et al., 2014) and thus strengthened the monsoon.

Our dinocyst data also show a significant increase in percentages of Brigantedinium spp. and Echinidinium spp. at around $15.5 \pm 0.4 \mathrm{kaBP}$ (limit between palynozones B and C; Fig. 8). Their modern distributions in the tropics are related to both nutrient-enriched waters and, more specifically for Echinidinium spp., to high river-discharges (Zonneveld et al., 2013). This is consistent with the strong increase in terrigenous inputs observed at that time in the same core (Bayon et al., 2012; Fig. 8). The equatorial species $O$. aguinawense also appeared shortly at around $15.5 \mathrm{kaBP}$ (Fig. 8), suggesting near-equatorial conditions during this short event. Relative abundances of $L$. machaerophorum also increased again at $15.5 \mathrm{kaBP}$ but remained low in comparison with glacial ones, suggesting a specific switch in fluvial-sensitive dinocyst tracers between $L$. machaerophorum (glacial) and Echinidinium spp. (across and after the last deglaciation).

Among the thermophile species, Selenopemphix nephroides and especially Stelladinium reidii are the clearest signals of the post $15.5 \mathrm{kaBP}$ deglacial warming (Fig. 8). Both species are also considered good tracers for regimes of high trophic conditions (Zonneveld et al., 2013), in agreement with the recorded surface nutrient enrichment previously suggested during this period (cf. Brigantedinium spp. and Echinidinium spp.). Extremely low abundances of $O$. centrocarpum at that time could be interpreted as minor or non-existent influence of the BC in the study area (Fig. 8), while significant abundances of this species recorded in the GeoB1023 core (cf. Fig. 1; Shi et al., 1998) would conversely suggest a strengthening of this cold current. This may be the consequence of a $3^{\circ}$ southward latitudinal shift of the ABF between 15 and $7 \mathrm{kaBP}$ (Fig. 8), disconnecting the study area from the influence of the Benguela upwelling system.

\section{The tropical response of the Younger Dryas (YD)}

Significant dinocyst changes occurred between around $13 \pm 0.2$ and $11.5 \pm 0.35 \mathrm{kaBP}$ in both dinocyst and geochemical records (Fig. 8). The significant drop in the XRF $\mathrm{Ti} / \mathrm{Ca}$ ratio evidences a reduction in terrigenous input, while percentages of the thermophile species $S$. mirabilis, $S$. nephroides and $S$. reidii strongly decrease, suggesting a significant cooling of surface waters in the study area. The recorded cooling would be in agreement with the Younger Dryas timing (Lowe and Hoek, 2001) (Fig. 8). However, high abundances of Echinidinium spp. and Brigantedinium spp. during this interval suggest that nutrient-enriched river discharges still occurred at that time (Fig. 8). Wetter conditions could be explained by a suitable location of the TR above the Congo Basin, between Holocene and LGM mean locations (Arbuszewski et al., 2013; McGee et al., 2014). Furthermore, the weakening of the deglacial sea-level rise during this period (Grant et al., 2012) and therefore the decrease in associated continental shelf reworking (Marret et al., 2008) could explain the observed drop in terrigenous inputs and the long-term decreasing trend of Echinidinium spp. (Fig. 8). The absence of $T$. applanatum during the tropical response of the YD would also suggest the absence of upwelling cells in the study area (Fig. 7). Nevertheless, high abundance of $S$. quanta and S. membranaceus (Figs. 5 and 8), generally abundant in the vicinity of seasonal upwelling cells (Marret and Zonneveld, 2003), may suggest the development of seasonal coastal upwelling close to the study area.

\subsubsection{The Holocene}

Acknowledging the weak chronostratigraphic constraint of the Holocene (cf. Fig. 2), some major subdivisions of the 


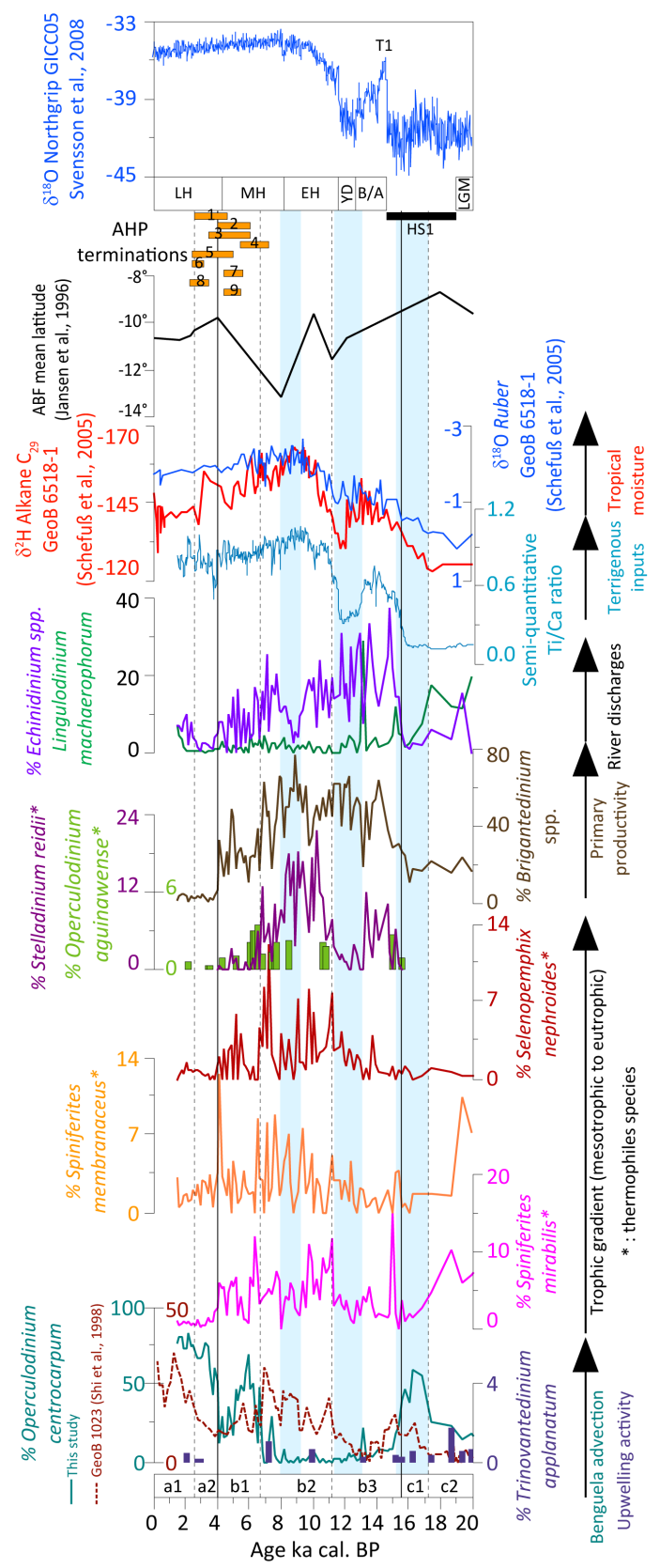

Figure 8. Temporal focus on the last $20 \mathrm{kyr}$. Sea-surface temperature changes are discussed using major dinocyst species classified according to their trophic affinity: Spiniferites mirabilis, Spiniferites membranaceus, Selenopemphix nephroides and Stelladinium reidii. Sea-surface salinity changes are discussed using Echinidinium spp., Operculodinium aguinawense, Lingulodinium machaerophorum, in addition to stable isotopic signals from core GeoB6518-1 (Schefuß et al., 2005). Upwelling activity and Benguela Current activity are respectively discussed using, respectively, Trinovantedinium applanatum and Operculodinium centrocarpum percentages with the KZAI-01 core, together with the latitudinal location of the Angola-Benguela Front (Jansen et al., 1996) and O. Centrocarpum relative abundances acquired in the Benguela upwelling system on the GeoB1023 core (Shi et al., 1998). Higher primary productivity conditions in the study area are indirectly discussed using Brigantedinium spp. percentages. XRF Ti / Ca ratio obtained on the KZAI-01 core allows discussing past terrigenous supplies. NGRIP (NorthGrip ice-core) $\delta^{18} \mathrm{O}$ (GICC05 timescale; Svensson et al., 2008) is also displayed in parallel with the last deglaciation. Holocene (Walker et al., 2012) subdivisions: Last Glacial Maximum (LGM), Heinrich Stadial 1 (HS1), Bølling-Allerød (B/A), Younger Dryas (YD), early Holocene (EH), mid-Holocene ( $\mathrm{MH}$ ) and late Holocene ( $\mathrm{LH})$. Blue bands correspond to cold and dry events recorded with dinocyst assemblages. African Humid Period (AHP) terminations are also depicted according to the literature (orange bars): 1. Kröpelin et al. (2008); 2. Shanahan et al. (2015); 3. Hély et al. (2009); 4. Lézine et al. (2005); 5. Lebamba et al. (2012); 6. Lézine et al. (2013); 7. Tierney and deMenocal (2013); 8. Shanahan et al. (2012); 9. deMenocal et al. (2000). Palynozones subdivisions are also highlighted (aX, bX; cf. Figs. 4 and 5). 
Holocene (early, mid- and late Holocene) can nevertheless be discussed.

\section{The early Holocene and the African Humid Period}

Across the Holocene, the African Humid Period (AHP) is a significantly warmer and wetter period that occurred between around 14.5 and $5 \mathrm{kaBP}$ (deMenocal et al., 2000; Shanahan et al., 2015). At that time, the TR was characterized by a wider latitudinal extension of up to several degrees poleward (Stager et al., 2011; Arbuszewski et al., 2013; McGee et al., 2014). Previous dinocyst studies showed that the AHP was characterized by the gradual bloom of thermophile ( $S$. mirabilis) and low-salinity (O. aguinawense) species, induced by strengthened river discharges from the beginning of the Holocene (Dupont and Behling, 2006; Kim et al., 2010; Marret et al., 2013).

Similar to these studies, our record also evidences a strengthening of nutrient-enriched river discharges from the onset of the last deglaciation (Fig. 8; cf. Sect. 5.2.1). However, significant occurrences of $O$. aguinawense between around $11 \pm 0.35$ and $2 \pm 0.2 \mathrm{kaBP}$ (Fig. 8) delimit the effective wettest period, also characterized by the highest abundances of both mesotrophic and eutrophic thermophile species (Fig. 8). High SST recorded at the beginning of the Holocene are also well correlated with alkenone SST reconstructions from core GeoB6518 (Schefuß et al., 2005), synchronously with the early Holocene timing (Fig. 8). It is interesting to note that, during this Holocene climatic optimum, our dinocyst data show a sharp drop in Echinidinium spp. relative abundances between 8 and $7 \mathrm{ka} \mathrm{BP}$, synchronously with a drop in thermophile species (Fig. 8). This could suggest a 1000-year-long cooler and drier event that occurred during the early- and mid-Holocene transition (Walker et al., 2012).

\section{The mid-Holocene transition and the end of the African Humid Period}

The timing of the AHP termination varies significantly between studies, i.e around $2.5 \mathrm{ka}$ BP (Kröpelin et al., 2008; Lézine et al., 2013; Shanahan et al., 2012; Lebamba et al., 2012), 4 ka BP (deMenocal et al., 2000; Hély et al., 2009; Tierney and deMenocal, 2013; Shanahan et al., 2015), or even earlier at around $5.3 \mathrm{ka} \mathrm{BP}$ (Lézine et al., 2005). Consequently, the duration of the AHP also varies between these, from a few centuries to a few thousand years according to the references mentioned above (Fig. 8).

In our data, we observe two events characterized by abrupt cooling and drying conditions. The first decline occurred abruptly between $7 \pm 0.15$ and $6 \pm 0.1 \mathrm{kaBP}$ (transition between sub-palynozones b1 and b2), illustrated by the sharp drop in heterotrophic taxa percentages, especially Brigantedinium spp., S. reidii and S. nephroides (Fig. 8), in parallel with high relative abundances of $O$. centrocarpum.
This suggests an environmental change from eutrophic to less nutrient-rich surface waters, probably allowing the observed development of mesotrophic taxa, such as S. mirabilis (Fig. 8). This decrease does not appear as a dry event, due to (i) the persistence of high Echinidinium spp. percentages, with, however, a long-term decreasing trend obvious since $15.5 \pm 0.4 \mathrm{kaBP}$ (Fig. 8), and (ii) the persistence of $O$. aguinawense (today related to near-equatorial hydrological conditions; cf. Fig. 6) which reached its highest relative abundances during this interval (sub-palynozone b1, Fig. 8).

The second decrease occurred abruptly between $4 \pm 0.08$ and $3.5 \pm 0.08 \mathrm{kaBP}$ (transition between palynozones A and B; Fig. 8), as displayed by a general drop in both heterotrophic and thermophile cyst percentages, while $O$. centrocarpum rapidly became the major dinocyst species (Fig. 8). As we discussed above from crossed information related to total dinocyst concentrations and community indexes (dominance versus diversity; cf. Sect. 4.1 and Fig. 3), the interval ranging from $4 \pm 0.08$ to $2.5 \pm 0.08 \mathrm{ka} \mathrm{BP}$ (subpalynozone a2; Fig. 8) is probably characterized by massive advection of $O$. centrocarpum cysts. However, removing $O$. centrocarpum percentages from the abundance calculations of other taxa will not erase the observed shift discussed above for heterotrophic and thermophile dinocysts, clearly related to the $4-3.5 \mathrm{ka} \mathrm{BP}$ period.

\section{The late Holocene}

Right after $3.5 \pm 0.08 \mathrm{ka}$ BP the interval appears to be one of the coolest and driest periods recorded in core KZAI-01, as evidenced by the strong dominance of $O$. centrocarpum and as also previously observed in the GeoB1023 core (Fig. 8; Shi et al., 1998). This could be the consequence of a strengthened $\mathrm{BC}$ activity, maybe also related to a $4^{\circ}$ northward shift of the ABF, well recorded during the mid- to late Holocene (Fig. 8, Jansen et al., 1996).

Finally, from $2.5 \pm 0.08 \mathrm{kaBP}$ onward (subpalynozone a1), a recovery of $L$. machaerophorum and Echinidinium spp. percentages is observed in parallel with low occurrences of $O$. aguinawense (Figs. 5 and 8), suggesting a slight reincrease in wetter conditions. However, despite the general tropical warming observed in several SST reconstructions over this period (Schefuß et al., 2005; Weldeab et al., 2005; Dyez et al., 2014), all thermophile cyst percentages remain null or very low (Fig. 8). The recovery of wetter conditions may be explained by the optimum of the precession index around $3 \mathrm{kaBP}$ (Fig. 7), which implies the correspondence between austral summer and Earth's perihelion and allows the establishment of wetter and warmer conditions in the Southern Hemisphere.

The Holocene, as recorded in core KZAI-01, can thus be divided into three major periods. The earliest interval $(11 \pm 0.35$ to $6.5 \pm 0.1 \mathrm{ka} \mathrm{BP})$ is also the warmest and wettest period, followed, between $6.5 \pm 0.1$ and $4 \pm 0.08 \mathrm{ka} \mathrm{BP}$, by a less warm and humid period, characterized by the progres- 
sive recovery of the BC activity. Finally, after $4 \mathrm{ka}$ BP, a major long-term cooling and drying period is gradually pondered by a progressive recovery of river discharges in the study area since $2.5 \mathrm{ka} \mathrm{BP}$.

\section{Conclusions}

Analysis of dinocyst assemblages in core KZAI-01 has permitted an investigation of land-sea-atmosphere linkages off the Congo River mouth over the last 44 kyr. Our dinocyst data evidence a great influence of nutrient-rich river discharges caused by latitudinal migrations of the tropical rain belt, forced by different orbital configurations and especially regarding the combination "precession minima - obliquity maxima". Furthermore, while most studies describe the LGM as a "cold and dry" period in the tropics, thermophile and river-plume dinocysts evidence here a pattern relatively similar to modern warm equatorial assemblages. The LGM appears to be a complex period characterized by a southward shift of the monsoonal belt and of warm surface waters, bringing heat and moisture. This illustrates complex dynamics that warrant model simulations to explore the underlying mechanisms that occurred across this specific climate interval.

This high-resolution study has also permitted us to discriminate between major climate periods of the last deglaciation in good correspondence to Northern Hemisphere highlatitude millennial-scale oscillations. We also discuss the timing of the equatorial response of the African Humid Period and the two-step decrease in heat and moisture conditions in the study area. Further work will involve a regionalscale study including other dinocyst records to reconstruct sea-surface environments in relation to latitudinal shifts in the tropical rain belt along the western African coast as well as model-data intercomparisons for different snapshots across the last glacial, deglacial and Holocene periods.

\section{Data availability}

River shapefiles, the coastline and the gridlines come from Natural Earth public website, http://www.naturalearthdata. $\mathrm{com} /$. The Milankovitch cycles dipslayed in Fig. 7 can be found here https://www.ncdc.noaa.gov/data-access/ paleoclimatology-data/datasets/climate-forcing. The geochemical elemental dataset of core GeoB6518-1 (Fig. 7) can be found here : https://doi.pangaea.de/10.1594/PANGAEA. 757398. Also on core GeoB6518-1, the isotopic reconstruction (Fig. 7) can be found here https://doi.pangaea. de/10.1594/PANGAEA.327243. Ba/Ca ratio reconstruction displayed in Fig. 7 can be found here: https://www. ncdc.noaa.gov/cdo/f?p=519:1:::::P1_STUDY_ID:5596. Precipitations reconstructions displayed in Fig. 7 can be found here https://www.ncdc.noaa.gov/cdo/f?p=519:1::::: P1_study_id:6213. Finally, Sea-Surface Temperatures dis- played in Fig. 1 can be found here http://www.esrl.noaa.gov/ $\mathrm{psd} / \mathrm{data} /$ gridded/data.cobe2.html.

\section{The Supplement related to this article is available online at doi:10.5194/bg-13-4823-2016-supplement.}

Acknowledgements. William Hardy's $\mathrm{PhD}$ was funded by the Brittany Region and this work was supported by the "Laboratoire d'Excellence" LabexMER (ANR-10-LABX-19) and co-funded by a grant from the French government under the program "Investissements d'Avenir". We thank B. Dennielou (Ifremer, Brest) for access to core KZAI-01. We thank the two anonymous reviewers for their constructive comments that helped to improve this manuscript.

Edited by: M. Kienast

Reviewed by: two anonymous referees

\section{References}

Amante, C. and Eakins, B. W.: ETOPO1 1 Arc-Minute Global Relief Model: Procedures, Data Sources and Analysis, NOAA Technical Memorandum NESDIS NGDC-24, National Geophysical Data Center, NOAA, doi:10.7289/V5C8276M, 2009.

Anhuf, D., Ledru, M.-P., Behling, H., Da Cruz Jr., F. W., Cordeiro, R. C., Van der Hammen, T., karmann, I., Marengo, J. A., De Oliveira, P. E., Pessenda, L., Siffedine, A., Albuquerque, A. L., and Da Silva Dias, P. L.: Paleo-environmental change in Amazonian and African rainforest during the LGM, Palaeogeogr. Palaeocl., 239, 510-527, 2006.

Anka, Z., Séranne, M., Lopez, M., Scheck-Wenderoth, M., and Savoye, B.: The long-term evolution of the Congo deep-sea fan: A basin-wide view of the interaction between a giant submarine fan and a mature passive margin (ZaiAngo project), Tectonophysics, 470, 42-56, 2009.

Arbuszewski, J. A., deMenocal, P. B., Cléroux, C., Bradtmiller, L., and Mix, A.: Meridional shifts of the Atlantic intertropical convergence zone since the Last Glacial Maximum, Nat. Geosci., 6, 959-962, 2013.

Babonneau, N., Savoye, B., Cremer, M., and Klein, B.: Morphology and architecture of the present canyon and channel system of the Zaire deep-sea fan, Mar. Petrol. Geol., 19, 445-467, 2002.

Bayon, G., Dennielou, B., Etoubleau, J., Ponzevera, E., Toucanne, S., and Bermell, S.: Intensifying Weathering and Land Use in Iron Age Central Africa, Science, 335, 1219-1222, 2012.

Berger, A. and Loutre, M. F.: Insolation values for the climate of the last 10 million years, Quaternary Sci. Rev., 10, 297-317, 1991.

Bonnefille, R. and Chalié, F.: Pollen-inferred precipitation timeseries from equatorial mountains, Africa, the last $40 \mathrm{kyr} \mathrm{BP}$, Global Planet. Change, 26, 25-50, 2000.

Bosmans, J. H. C., Hilgen, F. J., Tuenter, E., and Lourens, L. J.: Obliquity forcing of low-latitude climate, Clim. Past, 11, 13351346, doi:10.5194/cp-11-1335-2015, 2015.

Bouimetarhan, I., Prange, M., Schefuß, E., Dupont, L., Lippold, J., Mulitza, S., and Zonneveld, K.: Sahel megadrought during Heinrich Stadial 1: evidence for a three-phase evolution of the low- 
and mid-level West African wind system, Quaternary Sci. Rev., 58, 66-76, 2012.

Bultot, F.: Atlas climatique du bassin congolais, I. N. É. A. C., 1971. Caley, T., Malaizé, B., Revel, M., Ducassou, E., Wainer, K., Ibrahim, M., Shoeaib, D., Migeon, S., and Marieu, V.: Orbital timing of the Indian, East Asian and African boreal monsoons and the concept of a "global monsoon", Quaternary Sci. Rev., 30, 3705-3715, 2011.

Collier, A. B. and Hughes, A. R. W.: Lightning and the African ITCZ, J. Atmos. Sol.-Terr. Phy., 73, 2392-2398, 2011.

da Cunha, L. C. and Buitenhuis, E. T.: Riverine influence on the tropical Atlantic Ocean biogeochemistry, Biogeosciences, 10, 6357-6373, doi:10.5194/bg-10-6357-2013, 2013.

deMenocal, P., Ortiz, J., Guilderson, T., Adkins, J., Sarnthein, M., Baker, L., and Yarusinsky, M.: Abrupt onset and termination of the African Humid Period:: rapid climate responses to gradual insolation forcing, Quaternary Sci. Rev., 19, 347-361, 2000.

deMenocal, P. B., Ruddiman, W. F., and Pokras, E. M.: Influences of High- and Low-Latitude Processes on African Terrestrial Climate: Pleistocene Eolian Records from Equatorial Atlantic Ocean Drilling Program Site 663, Paleoceanography, 8, 209-242, 1993.

Droz, L., Marsset, T., Ondréas, H., Lopez, M., Savoye, B., and SpyAnderson, F.-L.: Architecture of an active mud-rich turbidite system: The Zaire Fan (Congo-Angola margin southeast Atlantic) Results from ZaïAngo 1 and 2 cruises, AAPG Bulletin, 87, 11451168, 2003.

Dupont, L. and Behling, H.: Land-sea linkages during deglaciation: High-resolution records from the eastern Atlantic off the coast of Namibia and Angola (ODP site 1078), Quatern. Int., 148, 19-28, 2006.

Dupont, L. M., Marret, F., and Winn, K.: Land-sea correlation by means of terrestrial and marine palynomorphs from the equatorial East Atlantic: phasing of SE trade winds and the oceanic productivity, Palaeogeogr. Palaeocl., 142, 51-84, 1998.

Dyez, K. A., Zahn, R., and Hall, I. R.: Multicentennial Agulhas leakage variability and links to North Atlantic climate during the past 80000 years, Paleoceanography, 29, PA002698, doi:10.1002/2014PA002698, 2014.

Fatela, F. and Taborda, R.: Confidence limits of species proportions in microfossil assemblages, Mar. Micropaleontol., 45, 169-174, 2002.

Gordon, A. L., Bosley, K. T., and Aikman III, F.: Tropical atlantic water within the Benguela upwelling system at $27^{\circ} \mathrm{S}$, Deep-Sea Res. Pt. I, 42, 1-12, 1995.

Hansen, M. C., Potapov, P. V., Moore, R., Hancher, M., Turubanova, S. A., Tyukavina, A., Thau, D., Stehman, S. V., Goetz, S. J., Loveland, T. R., Kommareddy, A., Egorov, A., Chini, L., Justice, C. O., and Townshend, J. R. G.: High-Resolution Global Maps of 21st-Century Forest Cover Change, Science, 342, 850-853, 2013.

Heezen, B. C. and Hollister, C.: Deep-sea current evidence from abyssal sediments, Mar. Geol., 1, 141-174, 1964.

Hély, C., Braconnot, P., Watrin, J., and Zheng, W.: Climate and vegetation: Simulating the African humid period, C. R. Geosci., 341, 671-688, 2009.

Hirahara, S., Ishii, M., and Fukuda, Y.: Centennial-Scale Sea Surface Temperature Analysis and Its Uncertainty, J. Climate, 27, 57-75, 2013.
Holzwarth, U., Esper, O., and Zonneveld, K.: Distribution of organic-walled dinoflagellate cysts in shelf surface sediments of the Benguela upwelling system in relationship to environmental conditions, Mar. Micropaleontol., 64, 91-119, 2007.

Hsu, C.-P. F. and Wallace, J. M.: The Global Distribution of the Annual and Semiannual Cycles in Precipitation, Mon. Weather Rev., 104, 1093-1101, 1976.

Jansen, J. H. F., Ufkes, E., and Schneider, R. R.: Late Quaternary Movements of the Angola-Benguela Front, SE Atlantic, and Implications for Advection in the Equatorial Ocean, in The South Atlantic, Springer Berlin Heidelberg, 553-575, available at: http://scdproxy.univ-brest.fr:2068/chapter/10.1007/ 978-3-642-80353-6_28 (last access: 28 October 2014), 1996.

John Lowe, J. and Hoek, W. Z.: Inter-regional correlation of palaeoclimatic records for the Last Glacial-Interglacial Transition: a protocol for improved precision recommended by the INTIMATE project group, Quaternary Sci. Rev., 20, 1175-1187, 2001.

Khripounoff, A., Vangriesheim, A., Babonneau, N., Crassous, P., Dennielou, B., and Savoye, B.: Direct observation of intense turbidity current activity in the Zaire submarine valley at $4000 \mathrm{~m}$ water depth, Mar. Geol., 194, 151-158, 2003.

Kim, S.-Y., Scourse, J., Marret, F., and Lim, D.-I.: A 26,000-year integrated record of marine and terrestrial environmental change off Gabon, west equatorial Africa, Palaeogeogr. Palaeoclimatol., 297, 428-438, 2010.

Kröpelin, S., Verschuren, D., Lézine, A.-M., Eggermont, H., Cocquyt, C., Francus, P., Cazet, J.-P., Fagot, M., Rumes, B., Russell, J. M., Darius, F., Conley, D. J., Schuster, M., von Suchodoletz, H., and Engstrom, D. R.: Climate-Driven Ecosystem Succession in the Sahara: The Past 6000 Years, Science, 320, 765-768, 2008.

Lass, H. U. and Mohrholz, V.: On the interaction between the subtropical gyre and the Subtropical Cell on the shelf of the SE Atlantic, J. Mar. Syst., 74, 1-43, 2008.

Lebamba, J., Vincens, A., and Maley, J.: Pollen, vegetation change and climate at Lake Barombi Mbo (Cameroon) during the last ca. 33000 cal yr BP?: a numerical approach, Clim. Past, 8, 5978, doi:10.5194/cp-8-59-2012, 2012.

Leduc, G., Schneider, R., Kim, J.-H., and Lohmann, G.: Holocene and Eemian sea surface temperature trends as revealed by alkenone and $\mathrm{Mg} / \mathrm{Ca}$ paleothermometry, Quaternary Sci. Rev., 29, 989-1004, 2010.

Lempicka, M.: Lempicka (Magdalena), Bilan hydrique du bassin du fleuve Zaïre, 1ère Partie: Ecoulement du bassin 1950-1959, Kinshasa: Office National de la Recherche et du Développement (ONRD), 1971, Office National de la Recherche et du Développement (ONRD), Kinshasa, 147 pp., 1971.

Leroux, M.: The Meteorology and Climate of Tropical Africa, Marcel Leroux, Springer, available at: http://www.springer.com/us/ book/9783540426363 (last access: 14 December 2015), 2001.

Lézine, A.-M., Duplessy, J.-C., and Cazet, J.-P.: West African monsoon variability during the last deglaciation and the Holocene: Evidence from fresh water algae, pollen and isotope data from core KW31, Gulf of Guinea, Palaeogeogr. Palaeocl., 219, 225237, 2005.

Lézine, A.-M., Holl, A. F.-C., Lebamba, J., Vincens, A., AssiKhaudjis, C., Février, L., and Sultan, É.: Temporal relationship between Holocene human occupation and vegetation change 
along the northwestern margin of the Central African rainforest, C. R. Geosci., 345, 327-335, 2013.

Loomis, S. E., Russell, J. M., Ladd, B., Street-Perrott, F. A., and Sinninghe Damsté, J. S.: Calibration and application of the branched GDGT temperature proxy on East African lake sediments, Earth Planet. Sci. Lett., 357/358, 277-288, 2012.

Marret, F. and Kim, S.-Y.: Operculodinium aguinawense sp. nov., A Dinoflagellate Cyst from the Late Pleistocene and Recent Sediments of the East Equatorial Atlantic Ocean, Palynology, 33, 125-139, 2009.

Marret, F. and Zonneveld, K. A. F.: Atlas of modern organic-walled dinoflagellate cyst distribution, Rev. Palaeobot. Palyno., 125, 1200, 2003.

Marret, F., Maley, J., and Scourse, J.: Climatic instability in west equatorial Africa during the Mid- and Late Holocene, Quatern. Int., 150, 71-81, 2006.

Marret, F., Scourse, J., Kennedy, H., Ufkes, E., and Jansen, J. H. F.: Marine production in the Congo-influenced SE Atlantic over the past 30,000 years: A novel dinoflagellate-cyst based transfer function approach, Mar. Micropaleontol., 68, 198-222, 2008.

Marret, F., Kim, S.-Y., and Scourse, J.: A 30,000 yr record of landocean interaction in the eastern Gulf of Guinea, Quaternary Res., 80, 1-8, 2013.

McGee, D., Donohoe, A., Marshall, J., and Ferreira, D.: Changes in ITCZ location and cross-equatorial heat transport at the Last Glacial Maximum, Heinrich Stadial 1, and the mid-Holocene, Earth Planet. Sci. Lett., 390, 69-79, 2014.

Merlis, T. M., Schneider, T., Bordoni, S., and Eisenman, I.: The Tropical Precipitation Response to Orbital Precession, J. Climate, 26, 2010-2021, 2012.

Mix, A. C., Bard, E., and Schneider, R.: Environmental processes of the ice age: land, oceans, glaciers (EPILOG), Quaternary Sci. Rev., 20, 627-657, 2001.

Müller, P. J., Kirst, G., Ruhland, G., von Storch, I., and RosellMelé, A.: Calibration of the alkenone paleotemperature index U37K' based on core-tops from the eastern South Atlantic and the global ocean $\left(60^{\circ} \mathrm{N}-60^{\circ} \mathrm{S}\right)$, Geochim. Cosmochim. Ac., 62, 1757-1772, 1998.

Nicholson, S. E.: A revised picture of the structure of the "monsoon" and land ITCZ over West Africa, Clim. Dynam., 32, 11551171, 2009.

Picot, M., Droz, L., Marsset, T., Dennielou, B., and Bez, M.: Controls on turbidite sedimentation: Insights from a quantitative approach of submarine channel and lobe architecture (Late Quaternary Congo Fan), Mar. Petrol. Geol., 72, 423-446, 2016.

Powers, L. A., Johnson, T. C., Werne, J. P., Castañeda, I. S., Hopmans, E. C., Sinninghe Damsté, J. S., and Schouten, S.: Large temperature variability in the southern African tropics since the Last Glacial Maximum, Geophys. Res. Lett., 32, L08706, doi:10.1029/2004GL022014, 2005.

Prance, G. T.: The vegetation of Africa, edited by: White, F., Brittonia, 36, 273-273, 1984.

Radi, T. and de Vernal, A.: Dinocysts as proxy of primary productivity in mid-high latitudes of the Northern Hemisphere, Mar. Micropaleontol., 68, 84-114, 2008.

Reimer, P.: IntCal13 and Marine13 Radiocarbon Age Calibration Curves 0-50,000 Years cal BP, Radiocarbon, 55, 1869-1887, 2013.
Savoye, B.: Zaiango 1 cruise report mission, doi:10.17600/98010100, 1998.

Savoye, B., Cochonat, P., Apprioual, R., Bain, O., Baltzer, A., Bellec, V., Beuzart, P., Bourillet, J.-F., Cagna, R., Cremer, M., Crusson, A., Dennielou, B., Diebler, D., Droz, L., Ennes, J.-C., Floch, G., Guiomar, M., Harmegnies, F., Kerbrat, R., Klein, B., Kuhn, H., Landuré, J.-Y., Lasnier, C., Le Drezen, E., Le Formal, J.P., Lopez, M., Loubrieu, B., Marsset, T., Migeon, S., Normand, A., Nouzé, H., Ondréas, H., Pelleau, P., Saget, P., Séranne, M., Sibuet, J.-C., Tofani, R., and Voisset, M.: Structure et évolution récente de l'éventail turbiditique du Zaïre : premiers résultats scientifiques des missions d'exploration Zaïango1 and 2 (marge Congo-Angola), Comptes Rendus de l'Académie des Sciences, Series IIA, Earth Planet. Sci., 331, 211-220, 2000.

Savoye, B., Babonneau, N., Dennielou, B., and Bez, M.: Geological overview of the Angola-Congo margin, the Congo deep-sea fan and its submarine valleys, Deep-Sea Res. Pt. II, 56, 2169-2182, 2009.

Schefuß, E., Schouten, S., and Schneider, R. R.: Climatic controls on central African hydrology during the past 20,000 years, Nature, 437, 1003-1006, 2005.

Schneider, R. R., Price, B., Müller, P. J., Kroon, D., and Alexander, I.: Monsoon related variations in Zaire (Congo) sediment load and influence of fluvial silicate supply on marine productivity in the east equatorial Atlantic during the last 200,000 years, Paleoceanography, 12, 463-481, 1997.

Shakun, J. D. and Carlson, A. E.: A global perspective on Last Glacial Maximum to Holocene climate change, Quaternary Sci. Rev., 29, 1801-1816, 2010.

Shanahan, T. M., Beck, J. W., Overpeck, J. T., McKay, N. P., Pigati, J. S., Peck, J. A., Scholz, C. A., Heil Jr., C. W., and King, J.: Late Quaternary sedimentological and climate changes at Lake Bosumtwi Ghana: New constraints from laminae analysis and radiocarbon age modeling, Palaeogeogr. Palaeocl., 361/362, 4960, 2012.

Shanahan, T. M., McKay, N. P., Hughen, K. A., Overpeck, J. T., Otto-Bliesner, B., Heil, C. W., King, J., Scholz, C. A., and Peck, J.: The time-transgressive termination of the African Humid Period, Nat. Geosci., 8, 140-144, 2015.

Shi, N., Dupont, L. M., Beug, H.-J., and Schneider, R.: Vegetation and climate changes during the last 21000 years in S.W. Africa based on a marine pollen record, Veget Hist Archaebot, 7, 127 140, 1998.

Stager, J. C., Mayewski, P. A., and Meeker, L. D.: Cooling cycles, Heinrich event 1, and the desiccation of Lake Victoria, Palaeogeogr. Palaeocl., 183, 169-178, 2002.

Stager, J. C., Ryves, D. B., Chase, B. M., and Pausata, F. S. R.: Catastrophic Drought in the Afro-Asian Monsoon Region During Heinrich Event 1, Science, 331, 1299-1302, 2011.

Svensson, A., Andersen, K. K., Bigler, M., Clausen, H. B., DahlJensen, D., Davies, S. M., Johnsen, S. J., Muscheler, R., Parrenin, F., Rasmussen, S. O., Röthlisberger, R., Seierstad, I., Steffensen, J. P., and Vinther, B. M.: A 60000 year Greenland stratigraphic ice core chronology, Clim. Past, 4, 47-57, doi:10.5194/cp-4-472008, 2008.

Weldeab, S., Schneider, R.R., Kölling, M., and Wefer, G.: Holocene African droughts relate to eastern equatorial Atlantic cooling, Geology, 33, 12, doi:10.1130/G21874.1, 2005. 
Tierney, J. E. and deMenocal, P. B.: Abrupt Shifts in Horn of Africa Hydroclimate Since the Last Glacial Maximum, Science, 342, 843-846, 2013.

Tierney, J. E., Russell, J. M., Sinninghe Damsté, J. S., Huang, Y., and Verschuren, D.: Late Quaternary behavior of the East African monsoon and the importance of the Congo Air Boundary, Quaternary Sci. Rev., 30, 798-807, 2011.

Tuenter, E., Weber, S. L., Hilgen, F. J., and Lourens, L. J.: The response of the African summer monsoon to remote and local forcing due to precession and obliquity, Global Planet. Change, 36, 219-235, 2003.

Voituriez, B.: Les sous-courants équatoriaux nord et sud et la formation des dômes thermiques tropicaux, Oceanol. Acta, 4, 497-506, 1981.

Walker, M. J. C., Berkelhammer, M., Björck, S., Cwynar, L. C., Fisher, D. A., Long, A. J., Lowe, J. J., Newnham, R. M., Rasmussen, S. O., and Weiss, H.: Formal subdivision of the Holocene Series/Epoch: a Discussion Paper by a Working Group of INTIMATE (Integration of ice-core, marine and terrestrial records) and the Subcommission on Quaternary Stratigraphy (International Commission on Stratigraphy), J. Quaternary Sci., 27, 649-659, 2012.
Weijers, J. W. H., Schefuß, E., Schouten, S., and Damsté, J. S. S.: Coupled Thermal and Hydrological Evolution of Tropical Africa over the Last Deglaciation, Science, 315, 1701-1704, 2007.

Weldeab, S.: Bipolar modulation of millennial-scale West African monsoon variability during the last glacial $(75,000-25,000$ years ago), Quaternary Sci. Rev., 40, 21-29, 2012.

Weldeab, S., Lea, D. W., Schneider, R. R., and Andersen, N.: 155,000 Years of West African Monsoon and Ocean Thermal Evolution, Science, 316, 1303-1307, 2007.

Zarriess, M. and Mackensen, A.: The tropical rainbelt and productivity changes off northwest Africa: A 31,000-year highresolution record, Mar. Micropaleontol., 76, 76-91, 2010.

Zonneveld, K. A. F., Marret, F., Versteegh, G. J. M., Bogus, K., Bonnet, S., Bouimetarhan, I., Crouch, E., de Vernal, A., Elshanawany, R., Edwards, L., Esper, O., Forke, S., Grøsfjeld, K., Henry, M., Holzwarth, U., Kielt, J.-F., Kim, S.-Y., Ladouceur, S., Ledu, D., Chen, L., Limoges, A., Londeix, L., Lu, S.-H., Mahmoud, M. S., Marino, G., Matsouka, K., Matthiessen, J., Mildenhal, D. C., Mudie, P., Neil, H. L., Pospelova, V., Qi, Y., Radi, T., Richerol, T., Rochon, A., Sangiorgi, F., Solignac, S., Turon, J.-L., Verleye, T., Wang, Y., Wang, Z., and Young, M.: Atlas of modern dinoflagellate cyst distribution based on 2405 data points, Rev. Palaeobot. Palyno., 191, 1-197, 2013. 